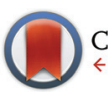

CrossMark click for updates

Cite this: Org. Biomol. Chem., 2015, 13,3393

Received 8th December 2014 Accepted 28th January 2015

DOI: 10.1039/c4ob02560a

www.rsc.org/obc

\title{
Hemisynthesis of deuteriated adenosylhopane and conversion into bacteriohopanetetrol by a cell-free system from Methylobacterium organophilum $\uparrow$
}

\author{
Wenjun Liu, ${ }^{a}$ Anne Bodlenner ${ }^{\mathrm{b}}$ and Michel Rohmer*a
}

Adenosylhopane is a putative precursor of the widespread bacterial $\mathrm{C}_{35}$ biohopanoids. A concise and flexible hemisynthesis of adenosylhopane has been developed including as key steps a cross metathesis between two olefins containing either the hopane moiety or a protected adenosine derivative and a subsequent diimide reduction of the resulting olefin. Reduction by deuteriated diimide allowed deuterium labelling. This synthetic protocol represents a versatile tool to access to deuteriated composite bacterial hopanoids required for biosynthetic studies. Deuteriated adenosylhopane was thus converted into bacteriohopanetetrol by a crude cell-free system from Methylobacterium organophilum in the presence of NADPH, showing for the first time the precursor to product relationship between these two bacterial metabolites.

\section{Introduction}

(22R)-Adenosylhopane 2 (Scheme 1) has been found in fairly large amounts in a few species of bacteria ${ }^{1 a-e}$ and in trace amounts in many hopanoid producing bacteria. ${ }^{2}$ Adenosylhopane (and structurally tentatively related hopanoids) is one of the most common hopanoids in soils, ${ }^{3 a-c}$ and the presence of this biomarker in recent sediments is interpreted in terms of transport of soils into sediments. ${ }^{3 b, 4,5}$

Adenosylhopane 2 is characterized by a unique carboncarbon bond between C-30 of the hopane moiety and C-5' of adenosine. The commonly occurring configuration of adenosylhopane was determined by circular dichroism and highfield NMR spectroscopy. ${ }^{1 a}$ Trace amounts of (22S)-adenosylhopane as the minor isomer was also reported from Rhodopseudomonas acidophila. ${ }^{1 b}$ Chemical conversion of adenosylhopane 2 into bacteriohopanetetrol 5 permitted the determination of the stereochemistry of all asymmetric centres of the side-chain of bacteriohopanetetrol as $22 R, 32 R, 33 R$ and $34 S .{ }^{1 b}$ Later the synthesis of the eight side chain diastereomers of bacteriohopanetetrol confirmed that the absolute configuration of the $\mathrm{C}_{5}$ unit was identical to that of a D-ribitol linked via its C-5 carbon

\footnotetext{
${ }^{a}$ Université de Strasbourg/CNRS, Institut Le Bel, 4 rue Blaise Pascal, F 67070 Strasbourg, Cedex, France.E-mail: mirohmer@unistra.fr

${ }^{b}$ Université de Strasbourg/CNRS, ECPM, 25 rue Becquerel, F 67087 Strasbourg, Cedex 2, France

$\dagger$ Electronic supplementary information (ESI) available. See DOI: 10.1039/ c4ob02560a
}

atom to the hopane moiety. ${ }^{6}$ The same configuration was also found for 35-aminobacteriohopanetriol 6 via chemical correlation with bacteriohopanetetrol. ${ }^{7}$ This side-chain configuration is consistent with the hypothesis deduced from the labelling experiments: the additional $\mathrm{C}_{5}$ unit of elongated hopanoids originates from a D-ribose derivative. ${ }^{8,9}$ Adenosylhopane was consequently considered as a possible intermediate in the biosynthesis of $\mathrm{C}_{35}$ hopanoids, leading to bacteriohopanetetrol 5 or aminobacteriohopanetriol 6 (Scheme 1)..$^{8-10}$ This hypothesis has been corroborated by the identification of the hpnG gene in Methylobacterium extorquens ${ }^{11}$ and Rhodopseudomonas palustris ${ }^{12}$ and the orf 14 gene in Streptomyces coelicolor: ${ }^{13}$ their deletion results in the accumulation of adenosylhopane 2 and in the absence of the major hopanoids, bacteriohopanetetrol 5 or aminobacteriohopanetriol 6 .

The elucidation of the biosynthesis of the side-chain of $\mathrm{C}_{35}$ hopanoids requires sufficient amounts of adenosylhopane for future enzyme tests. Two distinct methods are available to produce complex hopanoids: fermentation or chemical synthesis. The amphiphilic character and the poor solubility in most organic solvents of biohopanoids represent severe limitations for their production by fermentation. Moreover, fermentation is only appropriate for a few major compounds as many complex hopanoids are produced by bacteria in only trace amounts. In addition, isolation is until now only performed on acetylated derivatives requiring a final deprotection to get the native free metabolites, which is either cumbersome or simply not available (e.g. for adenosylhopane or bacteriohopanetetrol derivatives with carbamoyl groups). Chemical 

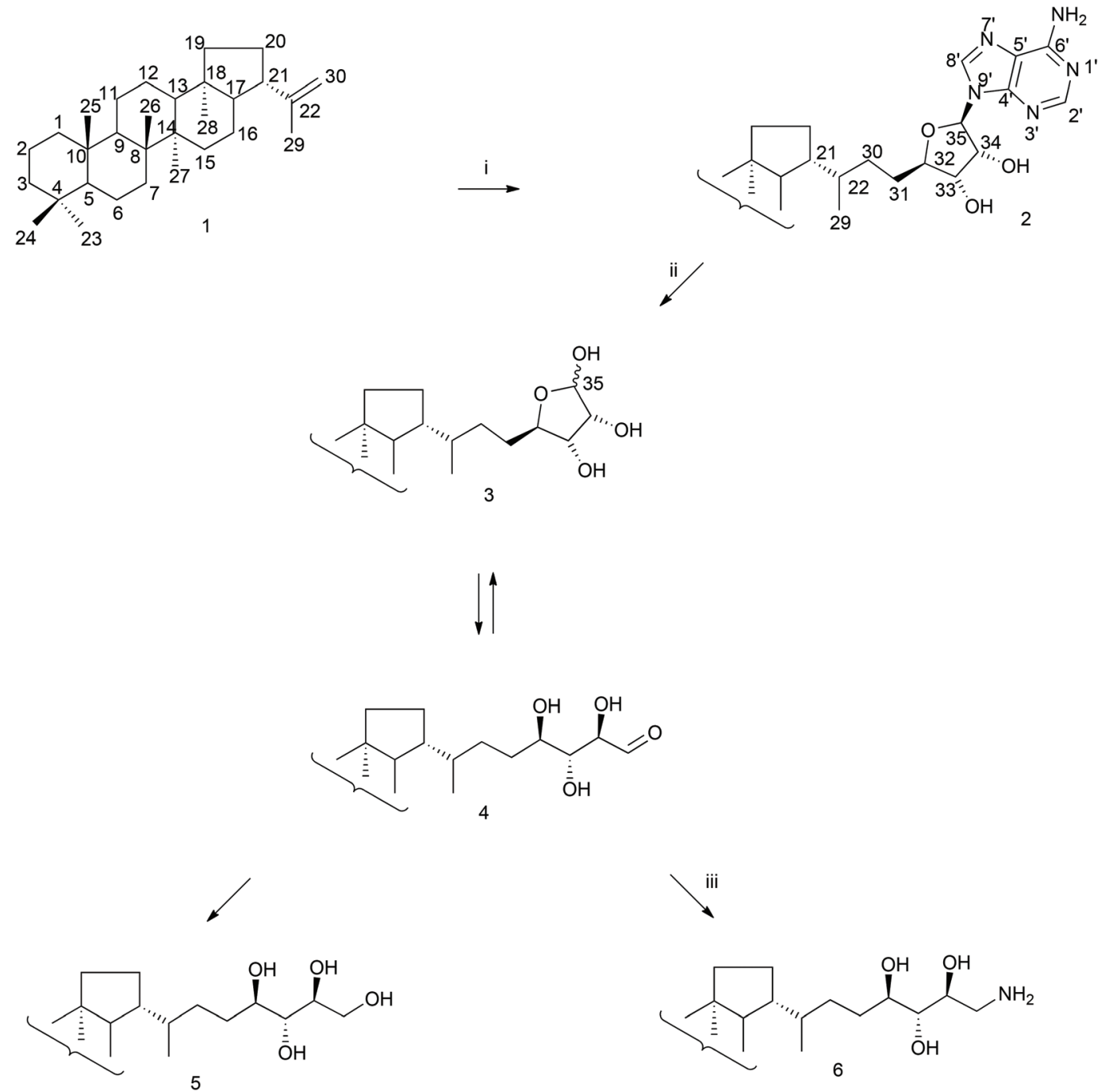

Scheme 1 Biogenetic scheme for the biosynthesis of $C_{35}$ bacterial hopanoids. Identified genes in Methylobacterium extorquens, Rhodopseudomonas palustris and Streptomyces coelicolor: (i) hpnH/orf15; (ii) hpnG/orf14; hpnO/orf18. ${ }^{10-13}$

synthesis, in contrast, allows an access to a broad range of naturally occurring hopanoids in sufficient amounts. Extensive work resulted in suitable syntheses of ribosylhopane, bacteriohopanetetrol and several other related structures. ${ }^{6,14-17}$ Some synthetic strategies are quite successful with excellent stereochemistry control and good overall yields.

No reliable synthesis is, however, available for adenosylhopane. The initial attempts towards the synthesis of adenosylhopane and related hopanoids were mainly based on two routes. The first strategy, inspired from the hypothetical biogenetic biosynthetic pathway, relies on a coupling between a $\mathrm{C}_{30}$ triterpene derivative and an adenosine derivative. Wittig-type coupling between a triterpene phosphonium salt with an adenosine-5'-aldehyde substrate led to the formation of adenosylhopane 2 in a very low yield, ${ }^{14}$ probably due to the steric hindrance induced by both the adenosine moiety and the pentacyclic triterpene skeleton in addition to the instability of the nucleoside- 5 '-aldehyde in the presence of the strong bases required for the generation of the non-stabilized phosphorane. ${ }^{18}$ Even the coupling strategy involving lithium (the smallest cation) activated hopane moiety, which was very efficient in ribosylhopane 3 synthesis, was disappointing to afford the bulkier 35-O-benzyl ribosylhopane analogue. ${ }^{17}$ The second strategy, which involves a glycosidic coupling between a ribosylhopane derivative and adenine in the presence of a Lewis acid was also rather unsuccessful, not only because of the poor solubility of adenine and the ribosylhopane derivative in acetonitrile, which promoted side reactions, but also because of the formation of both $35 \alpha$ and $35 \beta$ isomers of adenosylhopane $2 .^{14}$ Furthermore, the application of this methodology is also limited considering the number of synthetic steps.

This paper describes an efficient hemisynthesis of adenosylhopane including the possibility of deuterium labelling as well as the conversion of deuterium labelled adenosylhopane into bacteriohopanetetrol by a crude cell-free system form Methylobacterium organophilum, which represents the first 
direct and indisputable proof for a precursor to product relationship between adenosylhopane 2 and bacteriohopanetetrol 5.

\section{Results and discussion}

\section{Hemisynthesis of adenosylhopane}

The proposed strategy leading to adenosylhopane $\mathbf{2}$ is a convergent hemisynthesis with an excellent stereochemical control using commercially available starting materials. Moreover, in order to meet the need for isotopic labelled hopanoids for biosynthetic investigations, this strategy allows also the introduction of deuterium into the hopanoid structure in the last but one step. Our synthetic strategy relies on a cross-metathesis as the key coupling step between a methylene elongated hopane moiety $\mathbf{1 0}$ and a properly protected methylene elongated 5'-deoxy-5'-methyleneadenosine derivative 8 (Scheme 2). This approach has the advantage of preserving the stereogenic centres at C-22 on the hopane moiety and at C-4' of the ribose derivative and avoids the inconvenient glycosylation between adenine and ribose, ${ }^{14}$ which must be regio- and diastereoselective. Metathesis ${ }^{19}$ seemed quite attractive because of its high tolerance towards functional groups and bulky structures, ${ }^{20 a, b}$ its mildness and impressive efficiency, and the possibility of late labelling by deuteriation of the double bond. Cross metathesis is known to be more difficult than dimerization, ring closing or ring opening metathesis due to the lost advantages from statistics, entropy and ring tension relief respectively. The trick is to use alkenes having strong reactivity differences or an excess of one counterpart. ${ }^{21 a, b}$ It was, however, encouraging to note that Andrei and Wnuk succeeded in coupling a protected 5'-deoxy-5'-methyleneadenosine with $N$-Boc-protected sixcarbon amino acids bearing a terminal double bond, ${ }^{22}$ even if the methylenetriterpene $\mathbf{1 0}$ (Scheme 2) in our synthesis presents a steric hindrance closer to the terminal double bond than their cross-metathesis partner. Furthermore, both olefins $\mathbf{8}$ and $\mathbf{1 0}$ have the nice reactivity of terminal monosubstituted olefins $^{21}$ to counteract the steric hindrance present one bond away from the olefin.

Protected 5'-deoxy-5'-methyleneadenosine 8 (Scheme 2) was obtained by a Wittig methylene elongation of aldehyde 7 , obtained in five steps from commercially available $2^{\prime}, 3^{\prime}-O$-isopropylideneadenosine by an adaptation of two published methods ( $c f$. ESI, Scheme $\mathrm{S} 1 \dagger) .{ }^{23 a, b}$ In parallel, homohop-30ene 10 (Scheme 2), the triterpenic coupling partner, was synthesized in high yield via a Wittig reaction from $(22 S)$-hopan29-al 9, synthesized in four steps from hydroxyhopanone extracted from Dammar resin, ${ }^{15,24}$ and presenting the C-22 configuration of most bacterial hopanoids. ${ }^{25}$

\section{Cross metathesis}

Cross metathesis reactions between homohop-30-ene $\mathbf{1 0}$ and the 5 '-methylene adenosine derivative 8 were tested under different conditions (Scheme 2 and Table 1). Given the high value of both olefins, and hoping that their reactivity are different enough, ${ }^{21 a}$ initial attempts of cross metathesis were performed with stoichiometric amounts. Reaction with alkene $\mathbf{8}$ and one equivalent of homohopene $\mathbf{1 0}$ in the presence of Hoveyda-Grubbs catalyst (HII), did not, however, give the cross coupling product $\mathbf{1 1}$ under reflux conditions (Table 1, entry 1). This lack of reactivity for those two terminal alkenes probably resulted from the high steric hindrance in the expected metallacyclobutanyl transition state, together with an activation energy barrier too high to be overcome under classical thermic conditions. Coupling product $\mathbf{1 1}$ was, however, isolated with an up to $13 \%$ yield when the same reaction was performed under microwave irradiation (Table 1, entry 2). Dimer 15 (Scheme 2) was also isolated in $43 \%$ yield, resulting from the self-metathesis of the nucleoside substrate 8. Unreacted starting materials $\mathbf{8}$ and 10, were also isolated (Table 1, entry 2). The product of self-metathesis of homohop-30-ene $\mathbf{1 0}$ was not detected. Ruthenium catalyst Grubbs II (GII) promoted cross metathesis between $\mathbf{8}$ and $\mathbf{1 0}$ in a lower yield, (Table 1, entry 4), suggesting a higher efficiency of HII over GII with those olefins. Finally, the $N, N$-dimethylaminosulfonyl group containing Hoveyda-Grubbs-type complex catalyst Zhan-1B, was found almost as active as HII for this cross metathesis reaction, and similar yields were obtained for the coupling product $\mathbf{1 1}$ and dimer 15 (Table 1, entries 2 and 3).

Attempts to obtain olefin $\mathbf{1 1}$ from secondary cross metathesis between homohopene $\mathbf{1 0}$ and dimer $\mathbf{1 5}$ under microwave irradiation at $75{ }^{\circ} \mathrm{C}$ did not lead to the formation of the protected adenosylhopene $\mathbf{1 1}$, but allowed the recovery of the two starting reagents. The inability of dimer $\mathbf{1 5}$ to undergo secondary cross metathesis in addition to its formation from $\mathbf{8}$ under our conditions but its absence in the cross metathesis performed by Andrei and Wnuk with a type I olefin as cross metathesis partner, ${ }^{22}$ suggest that it belongs to type II olefins for cross metathesis reactions in Grubbs categorization of alkenes. ${ }^{21 a}$ Besides, the absence of the product of self-metathesis of homohop-30-ene $\mathbf{1 0}$ suggests that it is a type III olefin in spite of its terminal alkene.

Reacting two cross metathesis partners of different types using feedstock stoichiometries as low as 1:1 normally allows selective cross metathesis, but in our case the yield remained low. Given these features, the crucial point to obtain higher yield for coupling compound $\mathbf{1 1}$ was to maintain a low concentration of adenosine derivative 8 compared to that of homohopene 10, minimizing thus the amount of dimerization. A large excess (10 eq.) of the less reactive homohopene $\mathbf{1 0}$ was thus introduced, and, as expected, the yield of protected adenosylhopene 11 rose significantly from $13 \%$ to $59 \%$ in the presence of Zhan-1B catalyst under microwave irradiation (Table 1, entry 5). However, the cross metathesis yield still remained moderate, probably due to the low reactivity of homohopene $\mathbf{1 0}$. Increasing more the stoichiometry ratio was not possible for solubility reasons.

Under these conditions, the olefinic adenosine substrate 8 was fully consumed, resulting in the formation of $40 \%$ of dimer 15. A prolonged reaction time failed to further increase the yield in 11, supporting to a greater extent that dimer 15 
<smiles>CC(C=O)[C@H]1CCC23CC(CC12)C3</smiles><smiles>CC(C)(C)Nc1ncnc2c1ncn2[C@@H]1O[C@H](C=O)[C@H]2OC(C)(C)O[C@H]21</smiles><smiles>C=CC(C)[C@H]1CCC23CC2C13</smiles><smiles>C=C[C@H]1O[C@@H](n2cnc3c(NC(=O)c4ccccc4)ncnc32)[C@@H]2OC(C)(C)O[C@H]12</smiles><smiles>C#CC</smiles>

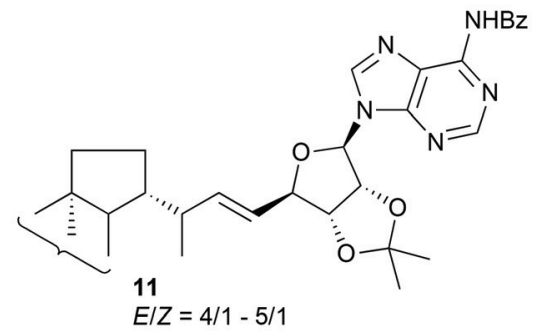

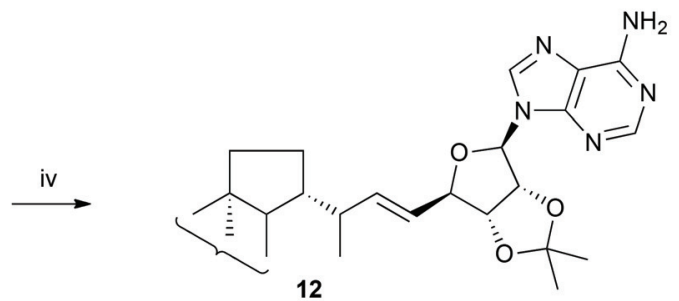

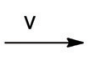<smiles>CC(CC[C@H]1O[C@@H](n2cnc3c(N)ncnc32)[C@@H]2OC(C)(C)O[C@H]12)[C@H]1CCC23CC(C2)C13</smiles><smiles></smiles>

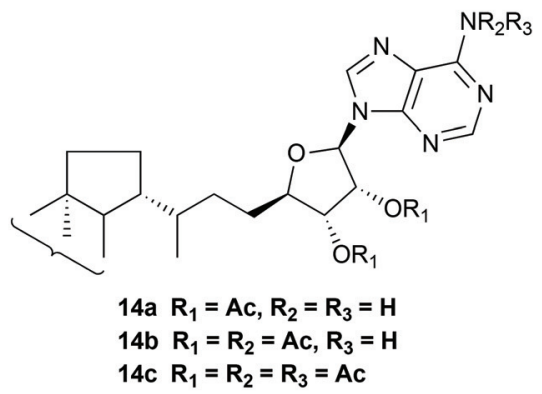<smiles>CC(C)(C)Nc1ncnc2c1ncn2[C@@H]1O[C@H](/C=C/[C@@H]2O[C@@H](n3cnc4c(NC(=O)c5ccccc5)ncnc43)[C@H]3OC(C)(C)O[C@H]23)[C@H]2OC(C)(C)O[C@H]21</smiles><smiles>COc1ccc(OC)c(C=NC(C)C)c1</smiles>

Zhan-1B

Scheme 2 Hemisynthesis of adenosylhopane 2. (i) $\mathrm{Ph}_{3} \mathrm{PCH}_{3} \mathrm{Br}, n-\mathrm{BuLi}, \mathrm{DMSO}-\mathrm{THF}, 50{ }^{\circ} \mathrm{C}, 98 \%$; (ii) $\mathrm{Ph}_{3} \mathrm{PCH} \mathrm{Br}_{3}, n-\mathrm{BuLi}, \mathrm{THF},-40{ }^{\circ} \mathrm{C}, 75 \%$; (iii) $\mathrm{meta}-$ thesis; (iv) $\mathrm{NH}_{4} \mathrm{OH}, \mathrm{H}_{2} \mathrm{O}, \mathrm{MeOH}, \mathrm{CH}_{2} \mathrm{Cl}_{2}, 4{ }^{\circ} \mathrm{C}, 91 \%$; (v) $\mathrm{PADA}, \mathrm{AcOH}, \mathrm{Py}, 90{ }^{\circ} \mathrm{C}, 73 \%$; (vi) $\mathrm{TFA}, \mathrm{CHCl}_{3}-\mathrm{CH}_{3} \mathrm{OH}, 0{ }^{\circ} \mathrm{C}, 92 \%$; (vii) $\mathrm{Ac} 2 \mathrm{O}, \mathrm{Py}$.

was indeed unable to undergo a secondary hetero-metathesis even with homohop-30-ene $\mathbf{1 0}$ in excess. The inability of compound $\mathbf{1 0}$ to homodimerize, probably due to a strong steric hindrance induced by the hopane ring system and the pseudoaxial position of the side chain, allowed the recycling of the large excess of olefin 10. 
Table 1 Cross-metathesis optimisation for the coupling of 10 and 8

\begin{tabular}{|c|c|c|c|c|}
\hline & Catalyst $^{a}$ & Conditions & $10 / 8$ ratio & Products \\
\hline 2 & H II & $\mathrm{MW}^{c}, 75^{\circ} \mathrm{C}, \mathrm{DCM}, 3 \mathrm{~h}$ & $1 / 1$ & $11(13 \%), 15(43 \%)$ \\
\hline 4 & G II & $\mathrm{MW}, 75^{\circ} \mathrm{C}, \mathrm{DCM}, 3 \mathrm{~h}$ & $1 / 1$ & $11(6 \%), 15^{d}$ \\
\hline 5 & Zhan-1B & $\mathrm{MW}, 75^{\circ} \mathrm{C}, \mathrm{DCM}, 3 \mathrm{~h}$ & $10 / 1$ & $11(59 \%), 15(40 \%)$ \\
\hline 6 & H II & in sealed tubes, DCM, overnight & $10 / 1$ & $11(51 \%), 15(46 \%)$ \\
\hline 7 & Zhan-1B & in sealed tubes, DCM, overnight & $10 / 1$ & $11(52 \%), 15(43 \%)$ \\
\hline
\end{tabular}

The same reactions were performed in sealed tubes without microwave irradiation (Table 1, entries 6 and 7). A night long reaction time was required to reach a slightly lower cross metathesis yield, indicating that the highly beneficial effects of microwave irradiation did not only arise from the rapid heating and pressure increase allowed in the microwave oven (purely thermal/kinetic effect), but also from some specific thermal microwave effect, such as wall effect and selective heating of strongly microwave-absorbing heterogeneous catalysts in a less polar reaction medium.

Furthermore, a polar solvent (e.g. dichloromethane) is required to enhance the heating effect of microwave. Although perfluorobenzene was reported to be capable of increasing the activity of cross metathesis catalysts, ${ }^{26}$ its apolar character probably led to less efficient heating by microwave, resulting in a lower yield of $\mathbf{1 1}$ in comparison to the one obtained with the use of dichloromethane (Table 1, entries 2 and 8).

As expected, the cross-metathesis product 11 presented predominantly the $E$ configuration as shown by the larger vicinal $J_{30,31}$ coupling constant of the vinylic protons in the spectrum of the major $E$ isomer $(15.4 \mathrm{~Hz})$ versus the smaller coupling constant in the spectrum of the minor $Z$ isomer $(11.0 \mathrm{~Hz})$. Based on the integration of the $32-\mathrm{H}$ and $33-\mathrm{H}$ signals of both protected $(E)$ - and $(Z)$-adenosylhop-32-ene 11 in the ${ }^{1} \mathrm{H}-\mathrm{NMR}$ spectrum, i.e. $(E)-32-\mathrm{H}$ at $4.74 \mathrm{ppm}$ and $(Z)-32-\mathrm{H}$ at $5.03 \mathrm{ppm}$ and $(E)-33-\mathrm{H}$ at $4.96 \mathrm{ppm}$ and $(Z)-33-\mathrm{H}$ at $4.85 \mathrm{ppm}$, the relative amount of $E$ isomer varied from $75 \%$ to $80 \%$.

Reduction of the double bond of the protected adenosylhopene 11 turned out to be more challenging than expected. Catalytic hydrogenation was disappointing even under pressure, and gave very low yields in the presence of $\mathrm{Pd} / \mathrm{C}(<10 \%)$, Adam's catalyst $(<10 \%)^{14,27}$ or no reaction with Wilkinson's ${ }^{28}$ and Crabtree's ${ }^{29}$ catalysts. Again, the steric hindrance around the double bond probably allowed only restricted access or no access at all for the different catalysts to the double bond. This hindered access to the olefin was circumvented by the use of the small sized diimide, a short-lived reagent that can be implicated in the reduction of nonpolar multiple bonds. In a concerted mechanism, cis-diimide is converted into $\mathrm{N}_{2}$ via a six-centre transition state corresponding formally to the syn addition of dihydrogen to the double bond. ${ }^{30 a, b}$ Taking into account that this reaction had to be extended to a deuterium labelled version, the acid promoted decarboxylation of potassium azodicarboxylate was chosen to generate diimide. ${ }^{31}$ Furthermore, the acid catalysis may speed up the equilibration of trans- and cis-diimide, favouring thus the hydrogen transfer from the cis-isomer to the alkene. Direct treatment of the $\mathrm{N}$-protected adenosylhopene $\mathbf{1 1}$ with potassium azodicarboxylate and acetic acid, however, led to the partial loss of the $6^{\prime}-N$ benzoyl group. This protecting group was therefore removed before diimide reduction using a saturated methanolic ammonia solution in dichloromethane to afford the $\mathrm{N}$-deprotected adenosylhopene 12 . Diimide reduction of its double bond was then achieved by a continuous addition of potassium azodicarboxylate and acetic acid for $36 \mathrm{~h}$ and afforded the expected protected adenosylhopane $\mathbf{1 3}$ in $73 \%$ yield. The reaction required a large excess of diimide and a long reaction time, probably because of the steric hindrance around the double bond, resulting in a low reduction rate in comparison to the one of the disproportionation of diimide into nitrogen and hydrazine, the major competing reaction consuming the reducing agent. In order to minimize this disproportionation, potassium azodicarboxylate was added to the reaction mixture in small portions. Acetic acid was added only when the nitrogen evolution had ceased, keeping thus a low diimide concentration. Water was also avoided because it had been reported to be a powerful inhibitor of diimide reductions in aprotic solvents such as pyridine. ${ }^{31}$ Finally, acid catalysed deprotection of the acetonide of $\mathbf{1 3}$ with a methanolic TFA solution afforded adenosylhopane 2 in high yield. The reaction was conducted at $0{ }^{\circ} \mathrm{C}$ on a rotary evaporator to continuously remove 2,2dimethoxypropane and shift the equilibrium. Purification of free adenosylhopane 2 also proved tricky, due to its amphiphilic character and its insolubility in polar solvents such as acetonitrile, methanol and water preventing purification by reversed phase HPLC. Purification was indeed successfully achieved by gravity column chromatography on silica gel with a polar ternary solvent (chloroform-methanol-ammonia).

\section{Deuterium labelling of adenosylhopane}

Only minor changes were required to obtain the deuterium labelled adenosylhopane 2-D (Scheme 3). Olefin 12 was first treated with $\mathrm{CH}_{3} \mathrm{O}^{2} \mathrm{H}$ to avoid the presence of extra protons coming from the exchangeable hydrogens of the amino group 

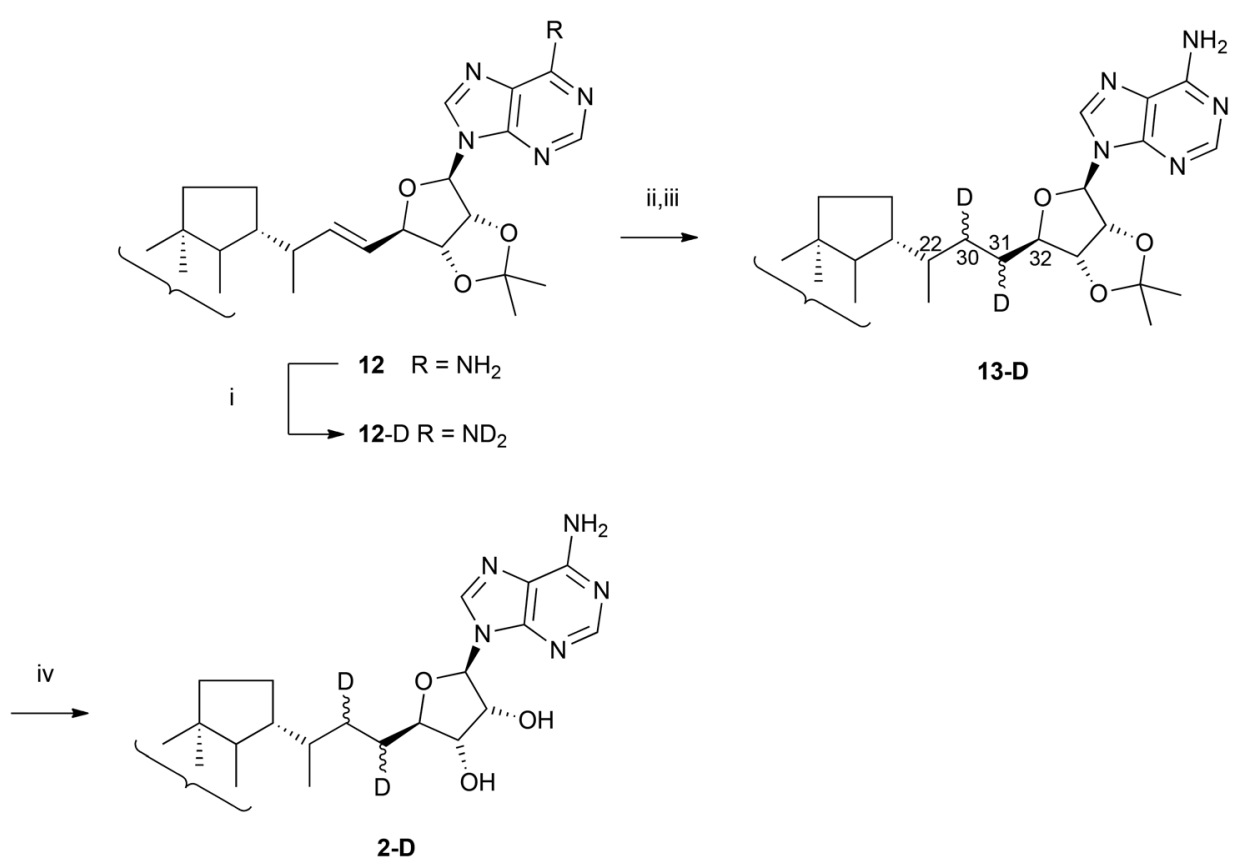

Scheme 3 Hemisynthesis of $\left(30,31-{ }^{2} \mathrm{H}_{2}\right)$ adenosylhopane 2-D. (i) MeOD; (ii) PADA, AcOD, $\mathrm{Py}, 90{ }^{\circ} \mathrm{C}$ and (iii) $\mathrm{H}_{2} \mathrm{O}, 60 \%, 2$ steps; (iv) TFA, $\mathrm{CHCl}{ }_{3}^{-}$ $\mathrm{CH}_{3} \mathrm{OH}, 0^{\circ} \mathrm{C}, 90 \%$.

to yield 12-D. Monodeuteriated acetic acid $\mathrm{CH}_{3} \mathrm{COO}^{2} \mathrm{H}(98 \%$ isotope abundance) was adopted as deuterium source to generate dideuteriodiimide. Reduction of olefin 12-D was much slower with deuteriodiimide than that with natural abundance diimide due to a primary deuterium isotope kinetic effect. This relatively slow reaction resulted in a decreased yield $(60 \%)$, but allowed to recover unreacted starting material 12 after $36 \mathrm{~h}$ treatment. The ${ }^{1} \mathrm{H}$-NMR spectrum of the recovered starting material 12 showed that the $E / Z$ ratio decreased from $5: 1$ before diimide reduction to $1: 1$ after reduction, indicating a faster hydrogenation rate of the $E$ olefin. This phenomenon has been frequently observed in diimide reductions and is attributed to the more cluttered transition state for a $Z$ olefin than for an $E$ olefin. ${ }^{30 a}$

The deuterium isotope abundance of the protected adenosylhopane 13-D was determined by mass spectrometry. In spite of all precautions against water contamination the deuterium content was not maximal, and the reaction resulted in a mixture of isotopomers: $\left(30,31{ }^{2} \mathrm{H}_{2}\right)-\mathbf{1 3}-\mathrm{D}(60 \%),\left(30-{ }^{2} \mathrm{H}_{1}\right)$ - and $\left(31-{ }^{2} \mathrm{H}_{1}\right)-13-\mathrm{D}(31 \%)$ and natural abundance $13(9 \%)$. This incomplete labelling is probably due to the large excess of $\mathrm{CH}_{3} \mathrm{COO}^{2} \mathrm{H}$ (60 eq.) having only a $98 \%$ isotope abundance and to the primary deuterium kinetic effect, leading to a mixture of $\mathrm{N}_{2}^{2} \mathrm{H}_{2}, \mathrm{~N}_{2}{ }^{2} \mathrm{H} \mathrm{H}$ and $\mathrm{N}_{2} \mathrm{H}_{2}$. Deuterium isotope abundance can be probably improved by using $\mathrm{CH}_{3} \mathrm{COO}^{2} \mathrm{H}$ with higher isotope abundance. The obtained labelling was, however, largely sufficient to perform the incorporation experiments.

\section{Structure of adenosylhopane and of its bisdeuteriated} isotopomer

To confirm the structure, synthetic adenosylhopane 2 was acetylated (Scheme 2). The spectroscopic data of adenosyl- hopane di-, tri- and tetraacetate 14a-c were compared with those of acetylated adenosylhopane isolated from bacteria. ${ }^{1, b}$ All the analytical data were consistent with those previously described. The assignments of the ${ }^{1} \mathrm{H}$ and ${ }^{13} \mathrm{C}-\mathrm{NMR}$ signals were made with the help of $2 \mathrm{D}$ NMR $\left({ }^{1} \mathrm{H}-{ }^{1} \mathrm{H}\right.$ COSY, HMBC and HSQC) and by comparison with those obtained on other hopanoids. ${ }^{16,32}$

The structure of protected bisdeuteriated $\left(31,32-{ }^{2} \mathrm{H}_{2}\right)$ adenosylhopane 13-D was confirmed by comparing its ${ }^{1} \mathrm{H}-$ and ${ }^{13} \mathrm{C}$-NMR spectra recorded in $\left({ }^{2} \mathrm{H}_{5}\right)$ pyridine with those of the corresponding natural abundance adenosylhopane derivative 18. Four different configurations at $\mathrm{C}-30$ and $\mathrm{C}-31$ were observed after $\mathrm{N}_{2}{ }^{2} \mathrm{H}_{2}$ reduction. Given that diimide reacts faster with the protected $(E)$-adenosylhopene $\mathbf{1 7}$, which is the dominant isomer, the major products resulting from syn addition of deuteriated diimide to the $E$ double bond should be protected $\left(30 R, 31 R_{-}^{-} \mathrm{H}_{2}\right)$ - and $\left(30 S, 31 S{ }_{-}{ }^{2} \mathrm{H}_{2}\right)$ adenosylhopane, and the $\left(30 R, 31 S^{-}{ }^{2} \mathrm{H}_{2}\right)$ - and $\left(30 S, 31 R^{-}{ }^{2} \mathrm{H}_{2}\right)$ adenosylhopane diastereomers would be generated by the reduction of protected $(Z)$-adenosylhopene by diimide ( $c f$. ESI and Scheme S2† for the discussion of the stereochemistry of those compounds and the interpretation of the NMR spectra).

\section{Conversion of adenosylhopane into bacteriohopanetetrol by a cell free system from Methylobacterium organophilum}

Methylobacterium organophilum has been chosen for its substantial production of hopanoids (up to $13 \mathrm{mg} \mathrm{g}^{-1}$, dry weight). ${ }^{33}$ It only synthesizes bacteriohopanetetrol derivatives, a glycoside and two ethers involving a carbapseudopentose moiety, free bacteriohopanetetrol being a minor hopanoid. This makes this bacterium a good candidate for incorporations 
with a crude cell-free system, since dilution of the deuterium labelled tetrol synthesized de novo from $\left({ }^{2} \mathrm{H}\right)$ adenosylhopane by the natural abundance endogenous tetrol synthesized during the culture will be minimal. In addition, in order to diminish this dilution, unbroken cells and large cell debris containing most of the hopanoids were removed by centrifugation, and the incubations were only performed with the resulting supernatant.

According to the hypothetical biogenetic scheme (Scheme 1), several steps are required for the conversion of adenosylhopane into bacteriohopanetetrol via ribosylhopane: ${ }^{10}$ a deadenylation into ribosylhopane, the hemiketal ringopening of ribosylhopane and a reduction. To obtain ribosylhopane 3 , the postulated precursor, ${ }^{10,13}$ two pathways have been proposed for the deadenylation: either a direct hydrolysis of adenosylhopane to ribosylhopane by a nucleosidase-like enzyme $^{12}$ or a phosphorolysis of the nucleotide hemiaminal with the loss of adenine by a purine nucleoside phosphorylase-like enzyme, yielding ribosylhopane phosphate. ${ }^{11}$ In this case, ribosylhopane 35-phosphate cannot be reduced and has first to be converted by a phosphatase into ribosylhopane 3 prior reduction. The final step is in all cases the reduction of the open aldehyde form of ribosylhopane by an NADPH-dependent aldose reductase-type enzyme (Bodlenner and Rohmer, unpublished results). For those reasons, the incubations were performed in a phosphate buffer or in a phosphate free triethylamine buffer in the presence of NADPH. Adenosylhopane was introduced as a THF solution. Although the use of this solvent is not common in enzymatic processes, THF is a good solvent for this amphiphilic hopanoid and has the advantage of being water miscible. Fortunately, the presence of $10 \%$ THF in the incubation medium did not affect the enzymes activities. A lipid extraction followed by acetylation allowed isolation of bacteriohopanetetrol tetraacetate and analysis of the deuterium labelling by electron impact GC-MS (Fig. 1). Deuterium incorporation was evaluated from the relative abundances of the $(m+1) / z$ and $(m+2) / z$ versus those of the $m / z$ signals (Table 2). Evidence that adenosylhopane was efficiently converted into BHT in a phosphate buffer was shown from intense ${ }^{2} \mathrm{H}$ labelling for all ions containing the side chain $[\mathrm{m} / \mathrm{z} 714$ $\left(\mathrm{M}^{+}\right), 699\left(\mathrm{M}^{+}-\mathrm{CH}_{3}\right), 654\left(\mathrm{M}^{+}-\mathrm{AcOH}\right), 493$ (fragment $\mathrm{B}$, ring C cleavage)], but not for those without the side-chain: $[\mathrm{m} / \mathrm{z} 369$ $\left(\mathrm{M}^{+}\right.$- side chain), 191 (fragment A, ring C cleavage)] (Fig. 1), ${ }^{34}$
Table 2 Incorporation of $\left(30,32-{ }^{2} \mathrm{H}_{2}\right)$ adenosylhopane 2-D into bacteriohopanetetrol 5 by cell-free systems from Methylobacterium organophilum: ${ }^{2} \mathrm{H}$ isotope abundances of fragments $\mathrm{A}$ and $\mathrm{B}^{\mathrm{a}}$

\begin{tabular}{|c|c|c|c|c|c|}
\hline & \multirow[b]{2}{*}{ Conditions $^{b}$} & \multicolumn{2}{|c|}{ Fragment A $(m / z=191)$} & \multicolumn{2}{|c|}{ Fragment B $(m / z=493)$} \\
\hline & & $m+1 / m(\%)$ & $m+2 / m(\%)$ & $m+1 / m(\%)$ & $m+2 / m(\%)$ \\
\hline 1 & Reference $^{c}$ & $20 \pm 4$ & $5 \pm 2$ & $28 \pm 3$ & $6 \pm 1$ \\
\hline 2 & A & 19 & 4 & 27 & 47 \\
\hline 3 & $\mathrm{~B}$ & 21 & 4 & 36 & 19 \\
\hline 4 & $\mathrm{C}$ & 24 & $1^{d}$ & 29 & 6 \\
\hline 5 & $\mathrm{D}$ & 19 & 2 & 28 & 6 \\
\hline
\end{tabular}

${ }^{a}$ Bacteriohopanetetrol was analysed as tetraacetate by GC/MS. Isotopic patterns of the fragments were measured according to the signal intensities observed for $\mathrm{m} / \mathrm{z}$ (reference signal, 100\%), $\mathrm{m} / \mathrm{z}+1$ and $\mathrm{m} / \mathrm{z}+$ 2. The standard deviation of the signal intensities of both fragments was calculated from the GC-MS analyses of seven samples of peracetylated bacteriohopanetetrol $\mathbf{5}$ isolated from seven different cell batches. A confidence interval of $95 \%$ can also be calculated by doubling the standard deviation value. The intensities if signals of fragments $\mathrm{A}$ and $\mathrm{B}$ have a $2 \%$ deviation. ${ }^{b}$ All the incorporation experiments were performed at $30{ }^{\circ} \mathrm{C}$ for $24 \mathrm{~h}$. A. Deuteriated adenosylhopane with cell-free extract in phosphate buffer. B. Deuteriated adenosylhopane with cell-free extract in TEA buffer. C. Decomposed deuteriated adenosylhopane after $24 \mathrm{~h}$ in phosphate buffer and then incubated with the cell-free extract in phosphate buffer. D. Deuteriated adenosylhopane with inactivated cell free system in phosphate buffer. ${ }^{c}$ Reference mass spectrum of natural abundance bacteriohopanetetrol tetraacetate isolated from the unbroken cells and cell debris pellets recovered after centrifugation yielding the supernatant utilised for incubations. ${ }^{d}$ High signal/noise ratio.

indicating that the ${ }^{2} \mathrm{H}$ labelling was strictly localized in the $\mathrm{C}_{5}$ side chain as expected (Table 2 , entry 2). In order to minimize the influence of the background noise, only the two most intense signals of the mass spectrum corresponding to fragments generated by ring $\mathrm{C}$ cleavage are shown and considered for evaluating the conversion of deuteriated adenosylhopane into bacteriohopanetetrol (Table 2).

Moreover, the ratio of bis- and monodeuteriated isotopomers $\left(d_{2} / d_{1}=1.9 / 1\right)$ of adenosylhopane was found unchanged in the labelled bacteriohopanetetrol $\left(d_{2} / d_{1}=1.9 / 1\right)$, indicating that incubated $\left({ }^{2} \mathrm{H}\right)$ adenosylhopane is the only deuterium source and that there is no significant isotope effect in this enzymatic conversion, which is logical as no reaction affects the deuterium labelled carbon atoms in this biosynthetic pathway.

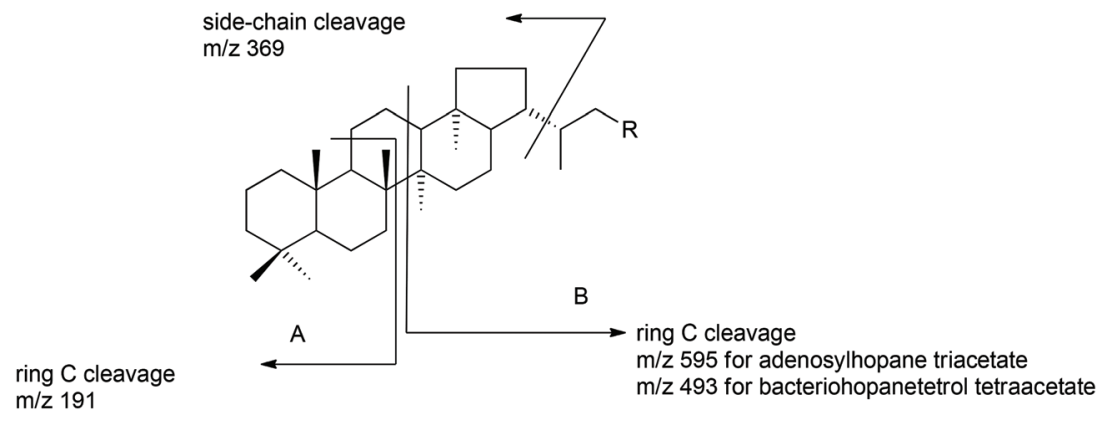

Fig. 1 Fragmentation of the hopane skeleton by electron impact mass spectrometry. 
In order to confirm that the overall conversion of $\left({ }^{2} \mathrm{H}\right)$ adenosylhopane 2-D into bacteriohopanetetrol $\mathbf{5}$ is purely enzymatic, $\left({ }^{2} \mathrm{H}\right)$ adenosylhopane 2-D was incubated with a cell-free system inactivated by boiling. No deuterium labelling was found in the bacteriohopanetetrol isolated from this assay (Table 2, entry 5).

A non-enzymatic conversion of $\left({ }^{2} \mathrm{H}\right)$ adenosylhopane 2-D into ribosylhopane 3 (or into ribosylhopane phosphate) was also excluded since a 3 days preincubation of $\left({ }^{2} \mathrm{H}\right)$ adenosylhopane in a phosphate buffer with $10 \%$ THF at $30^{\circ} \mathrm{C}$ did not lead to any detectable deuterium incorporation, even though a partial degradation of adenosylhopane was observed on TLC. Incubation of such a degraded sample resulted in no formation of ${ }^{2} \mathrm{H}$ labelled bacteriohopanetetrol, indicating that even the decomposition products of $\left({ }^{2} \mathrm{H}\right)$ adenosylhopane cannot be converted into bacteriohopanetetrol (Table 2, entry 4).

The present conversion of deuterium labelled adenosylhopane 2 into bacteriohopanetetrol $\mathbf{5}$ by a crude cell-free system of Methylobacterium organophilum in the presence of NADPH, indicates that the nucleoside side chain of adenosylhopane 2 is the precursor of the D-ribitol side chain of bacteriohopanetetrol 5. This biotransformation requires at least two reactions, depending on the nature of the nucleophile (phosphate or water) responsible of the cleavage of the glycosidic bond with adenine loss. Hoping to solve that question, the $\left({ }^{2} \mathrm{H}\right)$ adenosylhopane incubations with a cell-free system of $M$. organophilum were performed using two different buffers. Although, the conversion was significantly higher in the phosphate buffer than in the phosphate free triethylamine buffer (Table 2, entries 2 and 3), there is no clear cut conclusion in favour of one of the two proposed deadenylation mechanism. A sufficient phosphate concentration originating from the cells might indeed be still present in the triethylamine buffer to achieve the phosphorolysis, and a slight inhibitory effect on the putative aldose reductase of triethylamine/triethylammonium cannot be excluded to explain the lower yields. In fact, ribosylhopane is effectively an intermediate in biohopanoid biosynthesis. Deletion of the orf 18 gene in a $S$. coelicolor strain (corresponding to the hpnO gene in M. extorquens and $R$. palustris $)^{11,12}$ allowed to identify for the first time in the $\Delta$ orf18 mutant ribosylhopane 3 (Scheme 1), postulated twenty years ago as an intermediate in the biosynthesis of $\mathrm{C}_{35}$ hopanoids. ${ }^{10,15}$ It is accumulated in the absence of the putative transaminase encoded by the hpnO/orf18 gene catalysing the reductive transamination of the free aldehyde 4 into aminobacteriohopanetriol $6 .{ }^{13}$ Decisive proofs will be obtained later with tests performed with the isolated and purified enzymes.

In the final step, a reduction converts the open free aldehyde 4 of ribosylhopane 3 into bacteriohopanetetrol 5 , which has been found to be NADPH-dependent (Bodlenner and Rohmer, unpublished results). The reaction resembles the reduction catalysed by an aldose reductase, but the gene encoding this enzyme is yet unknown in hopanoid producing bacteria.

\section{Conclusion}

A highly efficient synthesis of adenosylhopane and its deuterium labelled homologue has been achieved from the coupling of homohop-30-ene and a 5'-methylene adenosine derivative via a cross-metathesis. This approach was found to be the only one able of linking the two highly hindered hopane and adenine counterparts to date, affording thus a total control of all the stereogenic centres of this large molecule. Moreover the metathesis step allows further labelling through the reduction of the introduced double bond by diimide. The deuterium labelled adenosylhopane was thus obtained and incubated with a supernatant of a crude cell-free system of Methylobacterium organophilum yielding deuterium labelled bacteriohopanetetrol as shown by EI-MS of its tetraacetate. This allowed for the first time to demonstrate the substrate to product relationship between adenosylhopane and bacteriohopanetetrol. This work opens also the way for the efficient synthesis of other biohopanoids and for further enzymatic studies on isolated enzymes required for the full elucidation of hopanoid biosynthesis.

\section{Experimental}

\section{Reagents and solvents}

Reagents were purchased from Sigma-Aldrich, Acros, Alfa Aesar or Carl Roth. Their purity was more than $98 \%$ in all cases. Dowex $50\left(\mathrm{H}^{+}\right)$resin was purchased from Aldrich and was activated right before use with a $10 \% \mathrm{HCl}$ solution in water.

All solvents were distilled before use. Dry solvents used in moisture sensitive reactions were obtained as follows: THF was freshly distilled from sodium benzophenone ketyl before use. $\mathrm{CH}_{2} \mathrm{Cl}_{2}$ was distilled over $\mathrm{P}_{2} \mathrm{O}_{5}$. Pyridine was distilled over $\mathrm{KOH}$ and then stored over molecular sieves (4 ̊). DMSO was purchased from Aldrich (sure sealed) and used directly.

\section{Purification techniques}

The progress of reactions was monitored by analytical thin layer chromatography using aluminum-coated Merck $60 \quad \mathrm{~F}_{254}$ silica plates. UV visible spots were directly visualized under UV light at $\lambda=254 \mathrm{~nm}$. Hopanoids were revealed on TLC plate by UV light $(\lambda=366 \mathrm{~nm})$ after spraying with a $0.1 \%$ berberine hydrochloride solution in EtOH.

Most products were purified by flash column chromatography using Merck 60 (230-400 mesh) silica gel and appropriate eluents. ${ }^{35}$ Adenosylhopane 2 and 2-D were purified by gravity column chromatography using Merck $60(63-200 \mu \mathrm{m})$ silica gel. Compounds in amounts below $10 \mathrm{mg}$ were purified via preparative thin layer chromatography using Merck $60 \mathrm{~F}_{254}$ silica gel plates ( $0.25 \mathrm{~mm}$ layer thickness).

\section{Spectroscopic analysis}

${ }^{1} \mathrm{H}-\mathrm{NMR}$ and ${ }^{13} \mathrm{C}-\mathrm{NMR}$ were performed on BRUKER Avance 600 spectrometer (600 MHz for ${ }^{1} \mathrm{H}, 150 \mathrm{MHz}$ for ${ }^{13} \mathrm{C}$ ), Bruker 
Biospin 500 spectrometer (500 MHz for ${ }^{1} \mathrm{H}, 125 \mathrm{MHz}$ for ${ }^{13} \mathrm{C}$ ) and BRUKER Avance 300 spectrometer $\left(300 \mathrm{MHz}\right.$ for ${ }^{1} \mathrm{H}$, $75 \mathrm{MHz}$ for ${ }^{13} \mathrm{C}$ ). Most of the measurements were carried out using $\mathrm{C}^{2} \mathrm{HCl}_{3}$ as solvent and with $\mathrm{CHCl}_{3}(\delta=7.26 \mathrm{ppm})$ as internal standard for ${ }^{1} \mathrm{H}-\mathrm{NMR}$ and $\mathrm{C}^{2} \mathrm{H} \mathrm{Cl}_{3}(\delta=77.0 \mathrm{ppm})$ for ${ }^{13} \mathrm{C}$-NMR. NMR spectra of adenosylhopane 2 and 2-D were recorded in $\left({ }^{2} \mathrm{H}_{5}\right)$ pyridine as solvent and with $\left({ }^{2} \mathrm{H}_{4}\right)$ pyridine ( $\delta=8.73,7.58$ and $7.21 \mathrm{ppm}$ ) as internal standard for ${ }^{1} \mathrm{H}-\mathrm{NMR}$ and $\left({ }^{2} \mathrm{H}_{5}\right)$ pyridine $(\delta=149.9,135.5$ and $123.5 \mathrm{ppm})$ for ${ }^{13} \mathrm{C}-\mathrm{NMR}$. The following abbreviations represent the multiplicity of the NMR signals: s, singlet; d, doublet; t, triplet; q, quadruplet; m, multiplet; dd, doublet of doublet; ddd, doublet of doublet of doublet; dddd, doublet of doublet of doublet of doublet; arom., aromatic protons or carbon atoms; br, broad.

${ }^{1} \mathrm{H}$ - and ${ }^{13} \mathrm{C}-\mathrm{NMR}$ assignments of hopanoids were based on earlier assignments ${ }^{14,17,32}$ and were supported by additional experiments including DEPT, HSQC and HMBC techniques. ${ }^{13} \mathrm{C}$ shift values of the carbon atoms in the hopanoid skeleton did not depend significantly on the nature of the side-chain and remained virtually unchanged after introduction of new carbon atoms or functional groups in the $\mathrm{C}_{5}$ side-chain.

GC-MS spectra were acquired on a Thermo TSQ Quantum mass spectrometer connected to a Thermo Trace GC ultra gas chromatograph (PTV injector, HP-5 MS column, $30 \mathrm{~m}$, $0.25 \mathrm{~mm}$ internal diameter, $0.25 \mu \mathrm{m}$ film thickness). Helium (constant flow $1 \mathrm{~mL} \mathrm{~min}^{-1}$ ) was used as carrier gas. The temperature program for GC analysis was: $3 \mathrm{~min}$ at $55{ }^{\circ} \mathrm{C}$, from $55^{\circ} \mathrm{C}$ to $320^{\circ} \mathrm{C}$ at $10^{\circ} \mathrm{C} \mathrm{min}^{-1}$ and $50 \mathrm{~min}$ at $320^{\circ} \mathrm{C}$.

Mass spectra were obtained by direct inlet on a Thermo TSQ Quantum mass spectrometer at $70 \mathrm{eV}$ in the electron impact positive ionization mode (EIMS) over a mass range of 50-800 Da (cycle time $0.5 \mathrm{~s}$ ). The source temperature was set at $230{ }^{\circ} \mathrm{C}$.

ESI-HRMS mass spectra were carried out on a Bruker MicroTOF spectrometer.

Melting points were measured with a BIBBY SMP3 apparatus and are corrected with benzophenone (m.p. $48 \pm 1.5^{\circ} \mathrm{C}$ ). Optical rotations were measured on a Perkin Elmer 341 polarimeter at $20 \pm 2{ }^{\circ} \mathrm{C}$ and $589 \mathrm{~nm}$ using $10 \mathrm{~cm}$ length and $1 \mathrm{~mL}$ volume cell.

\section{(22S)-Homohop-30-ene (10)}

A suspension of $\mathrm{NaH}(126 \mathrm{mg}, 5 \mathrm{mmol})$ in DMSO $(2.5 \mathrm{~mL})$ was stirred at $75{ }^{\circ} \mathrm{C}$ for $50 \mathrm{~min}$. The light green suspension was cooled down to room temperature, added into a solution of $\mathrm{PPh}_{3} \mathrm{CH}_{3} \mathrm{Br}(1.9 \mathrm{~g}, 5.4 \mathrm{mmol})$ in DMSO $(27 \mathrm{~mL})$ and stirred at room temperature for $20 \mathrm{~min}$ to afford a light green-grey suspension. The resulting mixture was then added into a solution of aldehyde 9 (297 mg, $0.70 \mathrm{mmol})$ in THF (20 mL) and stirred overnight at $50{ }^{\circ} \mathrm{C}$. The reaction was quenched with water, and extracted three times with pentane. The combined organic phases were dried over anhydrous $\mathrm{Na}_{2} \mathrm{SO}_{4}$, filtered through cotton, and evaporated to dryness in vacuo to give an almost pure crystalline product, which was further purified by flash chromatography (petroleum ether) to yield the terminal olefin 10 (290 mg, 98\%). $R_{\mathrm{f}} 0.67$ (petroleum ether-EtOAc, $20: 1$ ).
M.p. $=203-205^{\circ} \mathrm{C}$.

${ }^{1} \mathrm{H}-\mathrm{NMR}\left(300 \mathrm{MHz}, \mathrm{C}^{2} \mathrm{HCl}_{3}\right): \delta / \mathrm{ppm}=5.53\left(1 \mathrm{H}, \mathrm{ddd}, J_{30,31 \mathrm{a}}=\right.$ $\left.17.8 \mathrm{~Hz}, J_{30,31 \mathrm{~b}}=9.5 \mathrm{~Hz}, J_{22,30}=9.1 \mathrm{~Hz}, 30-\mathrm{H}\right), 4.85(1 \mathrm{H}$, ddd, $\left.J_{30,31 \mathrm{a}}=17.8 \mathrm{~Hz}, J_{\text {gem }}=2.0 \mathrm{~Hz}, J_{22-31 \mathrm{a}}=0.5 \mathrm{~Hz}, 31-\mathrm{H}_{\mathrm{a}}\right), 4.85(1 \mathrm{H}$, $\left.\mathrm{dd}, J_{30,31 \mathrm{~b}}=9.5 \mathrm{~Hz}, J_{\text {gem }}=2.0 \mathrm{~Hz}, 31-\mathrm{H}_{\mathrm{b}}\right), 2.21\left(1 \mathrm{H}, \mathrm{ddq}, J_{21,22}=\right.$ $\left.9.7 \mathrm{~Hz}, J_{22,30}=9.1 \mathrm{~Hz}, J_{22,29}=6.5 \mathrm{~Hz}, 22-\mathrm{H}\right), 1.8\left(1 \mathrm{H}, \mathrm{tdd}, J_{21,22}=\right.$ $\left.9.7 \mathrm{~Hz}, J_{20,21}=J_{17,21}=4.8 \mathrm{~Hz}, 21-\mathrm{H}\right), 1.01\left(3 \mathrm{H}, \mathrm{d}, J_{22,29}=6.5 \mathrm{H}\right.$, $22 R-\mathrm{Me}$ ), 0.960 (6H, s, $8 \beta-\mathrm{Me}$ and $14 \alpha-\mathrm{Me}), 0.851$ ( $3 \mathrm{H}, \mathrm{s}, 4 \alpha-\mathrm{Me})$,

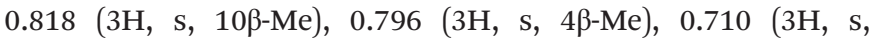
$18 \alpha-\mathrm{Me})$.

${ }^{13} \mathrm{C}-\mathrm{NMR}\left(75 \mathrm{MHz}, \mathrm{C}^{2} \mathrm{HCl}_{3}\right): \delta / \mathrm{ppm}=145.3,112.0,56.1$, 54.1, 50.4, 49.2, 45.0, 44.4, 42.2, 42.1, 41.9, 41.8, 41.7, 40.3, $37.4,33.5,33.4,33.3,33.2,27.6,24.0,22.3,22.0,21.6,20.9$, 18.7, 16.6, 15.9 .

EI-MS (direct inlet, positive mode $70 \mathrm{eV}): \mathrm{m} / \mathrm{z}=424\left(\mathrm{M}^{+}\right.$, 19\%), $409\left(\mathrm{M}^{+}-\mathrm{CH}_{3}, 5 \%\right), 369\left(\mathrm{M}^{+}\right.$-side chain, 20\%), 203 (ring C cleavage, 100\%), 191 (ring C cleavage, 88\%).

\section{$\mathrm{N}$-Benzoyl-33,34-O-isopropylidene-adenosylhopene (11) and homodimer (15)}

Procedure A. Olefins 10 (156 mg, $0.37 \mathrm{mmol}$ ) and 8 (15 mg, $0.037 \mathrm{mmol}$ ) and Ru-catalyst (10 mol\%) were dissolved in dry DCM $(3.6 \mathrm{~mL})$ at ambient temperature under an atmosphere of argon and the resulting solution was heated overnight at $75^{\circ} \mathrm{C}$ (oil bath) in a pressure tube (Ace glass). Volatiles were evaporated and the residue was purified by flash chromatography (DCM to DCM-MeOH $100: 3$ ) to afford compound 11 (15 mg, 52\%, $E / Z \sim 4: 1$ ) as a mixture of two isomers and dimer 15 ( $6 \mathrm{mg}, 43 \%)$ as a by-product.

Procedure B. Olefins 10 (210 mg, $0.49 \mathrm{mmol})$ and $8(20 \mathrm{mg}$, $0.049 \mathrm{mmol}$ ) and Ru-catalyst (10 mol\%) were dissolved in dry $\mathrm{CH}_{2} \mathrm{Cl}_{2}(5 \mathrm{~mL})$ in a sealed tube equipped with a Teflon-coated stirrer bar and heated under microwave irradiation at $75^{\circ} \mathrm{C}$ for $3 \mathrm{~h}$. The mixture was then evaporated to dryness in vacuo and purified by flash chromatography $\left(\mathrm{CH}_{2} \mathrm{Cl}_{2}\right.$ to $\mathrm{CH}_{2} \mathrm{Cl}_{2}-\mathrm{MeOH}$, $100: 3)$ to afford compound 11 (23 mg, 59\%, E/Z 4:1) and dimer 15 (7.5 mg, 40\%). Compound 11 was isolated as a colourless solid mixture of the $E / Z$ isomers that were not separated. $R_{\mathrm{f}} 0.47\left(\mathrm{CH}_{2} \mathrm{Cl}_{2}-\mathrm{MeOH}, 100: 3\right)$.

${ }^{1} \mathrm{H}-\mathrm{NMR}\left(300 \mathrm{MHz}, \mathrm{C}^{2} \mathrm{HCl}_{3}\right)$ of $(E)-\mathbf{1 1}$ and $(Z)-\mathbf{1 1}$ (subscripts " $E$ " and " $Z$ " characterize respectively the ${ }^{1} \mathrm{H}-\mathrm{NMR}$ signals of $(E)-\mathbf{1 1}$ and (Z)-11, which are respectively present in a $4: 1$ ratio): $\delta / \mathrm{ppm}=9.29(1 \mathrm{H}$, br. $\mathrm{s},-\mathrm{NHC}=\mathrm{O}), 8.82\left(1 \mathrm{H}, \mathrm{s}, 2^{\prime}-\mathrm{H}\right)$, $8.12\left(0.2 \mathrm{H}, \mathrm{s}, 8^{\prime}-\mathrm{H}_{Z}\right), 8.10\left(0.8 \mathrm{H}, \mathrm{s}, 8^{\prime}-\mathrm{H}_{E}\right), 8.04-8.01(2 \mathrm{H}, \mathrm{m}$, $\mathrm{Ar}-\mathrm{H}), 7.61-7.47$ (3H, m, Ar-H), $6.14\left(1 \mathrm{H}, \mathrm{d}, J_{34,35}=1.9 \mathrm{~Hz}, 35-\mathrm{H}_{Z}\right.$ and $\left.35-\mathrm{H}_{E}\right), 5.55\left(0.8 \mathrm{H}, \mathrm{dd}, J_{33,34}=6.2 \mathrm{~Hz}, J_{34,35}=1.9 \mathrm{~Hz}\right.$, $\left.34-\mathrm{H}_{E}\right), 5.51\left(0.2 \mathrm{H}\right.$, dd, $\left.J_{33,34}=6.1 \mathrm{~Hz}, J_{34,35}=1.8 \mathrm{~Hz}, 34-\mathrm{H}_{Z}\right)$, $5.46\left(0.8 \mathrm{H}, \mathrm{dd}, J_{30,31}=15.4 \mathrm{~Hz}, J_{22,30}=8.9 \mathrm{~Hz}, 30-\mathrm{H}_{E}\right), 5.37$ $\left(0.8 \mathrm{H}, \mathrm{dd}, J_{30,31}=15.4 \mathrm{~Hz}, J_{31,32}=7.4 \mathrm{~Hz}, 31-\mathrm{H}_{E}\right), 5.28(0.4 \mathrm{H}$, $\mathrm{dd}, J_{30,31}=11.0 \mathrm{~Hz}, J_{31,32}=8.7 \mathrm{~Hz}, 30-\mathrm{H}_{Z}$ and $\left.31-\mathrm{H}_{Z}\right), 5.03$ $\left(0.2 \mathrm{H}, \mathrm{dd}, J_{31,32}=8.7 \mathrm{~Hz}, J_{32,33}=3.0 \mathrm{~Hz}, 32-\mathrm{H}_{Z}\right), 4.96(0.8 \mathrm{H}, \mathrm{dd}$, $\left.J_{33,34}=6.2 \mathrm{~Hz}, J_{32,33}=3.0 \mathrm{~Hz}, 33-\mathrm{H}_{E}\right), 4.85\left(0.2 \mathrm{H}, \mathrm{dd}, J_{33,34}=\right.$ $\left.6.0 \mathrm{~Hz}, J_{32,33}=3.0 \mathrm{~Hz}, 33-\mathrm{H}_{Z}\right), 4.74\left(0.8 \mathrm{H}, \mathrm{dd}, J_{31,32}=7.3 \mathrm{~Hz}\right.$, $\left.J_{32,33}=2.8 \mathrm{~Hz}, 32-\mathrm{H}_{E}\right), 2.71-2.65\left(0.2 \mathrm{H}, \mathrm{m}, 22-\mathrm{H}_{Z}\right), 2.17-2.11$ $\left(0.8 \mathrm{H}, \mathrm{m}, 22-\mathrm{H}_{E}\right), 1.65$ and $1.41\left(6 \mathrm{H}, 2 \mathrm{~s}, \mathrm{Me}_{2} \mathrm{C}\right), 1.01(0.6 \mathrm{H}, \mathrm{d}$, $\left.J_{22,29}=6.2 \mathrm{~Hz}, 22 R-\mathrm{Me}_{Z}\right), 0.97$ and $0.95\left(1.2 \mathrm{H}, 2 \mathrm{~s}, 8 \beta-\mathrm{Me}_{Z}\right.$ and 
$\left.14 \alpha-\mathrm{Me}_{Z}\right), 0.93$ and $0.92\left(4.8 \mathrm{H}, 2 \mathrm{~s}, 8 \beta-\mathrm{Me}_{E}\right.$ and $\left.14 \alpha-\mathrm{Me}_{E}\right), 0.89$ $\left(2.4 \mathrm{H}, \mathrm{d}, J_{22,29}=6.4 \mathrm{~Hz}, 22 R-\mathrm{Me}_{E}\right), 0.84(18 \mathrm{H}, \mathrm{s}, 4 \alpha-\mathrm{Me}), 0.80$

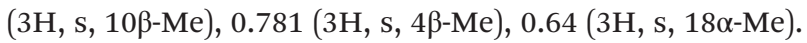

${ }^{13} \mathrm{C}-\mathrm{NMR}$ of the major isomer $(E)-\mathbf{1 1}\left(75 \mathrm{MHz}, \mathrm{C}^{2} \mathrm{HCl}_{3}\right)$ : $\delta / \mathrm{ppm}=164.5,152.6,151.1,149.6,142.1,133.6,132.7,128.7$, $127.8,124.5,123.5,114.3,91.2,88.6,84.8,84.4,56.0,54.0$, $50.3,49.1,44.8,44.3,42.0,41.8,41.7,41.5,40.5,40.2,37.3$, $33.4,33.3$, 33.2, 33.2, 27.5, 27.0, 25.4, 23.9, 21.9, 21.7, 21.5, 20.9, 18.6, 16.5, 15.9, 15.8 .

HRMS (ESI): $m / z[\mathrm{M}+\mathrm{Na}]^{+}$, calcd for $\mathrm{C}_{50} \mathrm{H}_{69} \mathrm{~N}_{5} \mathrm{NaO}_{4}{ }^{+}$ 826.524, found 826.524.

\section{Homodimer of $5^{\prime}$-methylene adenosine (15)}

Dimer 15 was isolated as a solid mixture of two $E / Z$ isomers $(\sim 3: 1) \cdot R_{\mathrm{f}}=0.16\left(\mathrm{CH}_{2} \mathrm{Cl}_{2}-\mathrm{MeOH}, 100: 3\right)$.

${ }^{1} \mathrm{H}-\mathrm{NMR}\left(300 \mathrm{MHz}, \mathrm{C}^{2} \mathrm{HCl}_{3}\right.$ ) (subscripts " $E$ " and " $Z$ " characterize respectively the ${ }^{1} \mathrm{H}-\mathrm{NMR}$ signals of $(E)-\mathbf{1 5}$ and $(Z)-\mathbf{1 5}$, which are respectively present in a $3: 1$ ratio): $\delta / \mathrm{ppm}=9.24$ $\left(1.5 \mathrm{H}\right.$, br. s, $\left.-\mathrm{NHBz}_{E}\right), 9.11\left(0.5 \mathrm{H}\right.$, br. s, $\left.-\mathrm{NHBz}_{Z}\right), 8.79(0.5 \mathrm{H}$, br. s, 2- $\left.\mathrm{H}_{Z}\right), 8.63\left(1.5 \mathrm{H}\right.$, br. s, $\left.2-\mathrm{H}_{E}\right), 8.10\left(0.5 \mathrm{H}, \mathrm{s}, 8-\mathrm{H}_{Z}\right)$, 8.04-8.02 (4H, m, Ar-H), $7.95\left(1.5 \mathrm{H}, \mathrm{s}, 8-\mathrm{H}_{E}\right), 7.64-7.44(6 \mathrm{H}, \mathrm{m}$, $\operatorname{Ar}-\mathrm{H}), 6.15\left(0.5 \mathrm{H}, \mathrm{d}, J_{1^{\prime}, 2^{\prime}}=1.5 \mathrm{~Hz}, 1^{\prime}-\mathrm{H}_{Z}\right), 6.06\left(1.5 \mathrm{H}, \mathrm{d}, J_{1^{\prime}, 2^{\prime}}=\right.$ $\left.1.7 \mathrm{~Hz}, 1^{\prime}-\mathrm{H}_{E}\right), 5.72\left(1.5 \mathrm{H}, \mathrm{dd}, J=3.4,1.5 \mathrm{~Hz}, 5^{\prime}-\mathrm{H}_{E}\right), 5.63(0.5 \mathrm{H}$, $\left.\mathrm{dd}, J=5.5,1.3 \mathrm{~Hz}, 5^{\prime}-\mathrm{H}_{Z}\right), 5.56\left(0.5 \mathrm{H}, \mathrm{dd}, J_{2^{\prime}, 3^{\prime}}=6.1 \mathrm{~Hz}, J_{1^{\prime}, 2^{\prime}}=\right.$ $\left.1.5 \mathrm{~Hz}, 2^{\prime}-\mathrm{H}_{Z}\right), 5.44\left(1.5 \mathrm{H}, \mathrm{dd}, J_{2^{\prime}, 3^{\prime}}=6.3 \mathrm{~Hz}, J_{1^{\prime}, 2^{\prime}}=1.7 \mathrm{~Hz}\right.$, $\left.2^{\prime}-\mathrm{H}_{E}\right), 5.14-5.11\left(0.5 \mathrm{H}, \mathrm{m}, 3^{\prime}-\mathrm{H}_{Z}\right), 4.94\left(1.5 \mathrm{H}, \mathrm{dd}, J_{2^{\prime}, 3^{\prime}}=6.3\right.$, $\left.J_{3^{\prime}, 4^{\prime}}=3.3 \mathrm{~Hz}, 3^{\prime}-\mathrm{H}_{E}\right)$, 4.69-4.67 $\left(0.5 \mathrm{H}, \mathrm{m}, 4^{\prime}-\mathrm{H}_{Z}\right), 4.63(1.5 \mathrm{H}, \mathrm{m}$, $\left.4^{\prime}-\mathrm{H}_{E}\right), 1.63$ and $1.38\left(3 \mathrm{H}, 2 \mathrm{~s}, \mathrm{Me}_{2} \mathrm{C}_{Z}\right), 1.59$ and $1.36(9 \mathrm{H}$, $\left.2 \mathrm{~s}, \mathrm{Me}_{2} \mathrm{C}_{E}\right)$.

${ }^{13} \mathrm{C}-\mathrm{NMR}\left(75 \mathrm{MHz}, \mathrm{C}^{2} \mathrm{HCl}_{3}\right): \delta / \mathrm{ppm}=164.7_{E}, 152.7_{Z}, 152.4_{E}$, $150.9_{E}, 149.8_{Z}, 149.7_{E}, 142.4_{Z}, 142.3_{E}, 133.5_{E}, 133.4_{Z}, 132.8_{Z}$, $132.7_{E}, 131.2_{Z}, 130.0_{E}, 128.9_{Z}, 128.7_{E}, 128.0_{E}, 127.9_{Z}, 123.6_{E}$, $114.6_{Z}, 114.5_{E}, 91.1_{Z}, 90.7_{E}, 87.3_{E}, 85.4_{Z}, 84.5_{E}, 84.3_{Z}, 84.0_{E}$, $83.5_{Z}, 27.0_{E}, 27.0_{Z}, 25.3_{Z}, 25.2_{E}$.

HRMS (ESI): $m / z[\mathrm{M}+\mathrm{Na}]^{+}$, calcd for $\mathrm{C}_{40} \mathrm{H}_{38} \mathrm{~N}_{10} \mathrm{NaO}_{8}{ }^{+}$ 809.277, found 809.277.

(E)-33,34-O-Isopropylidene adenosylhop-30-ene ((E)-12) and (Z)-33,34-O-isopropylidene adenosylhop-30-ene ((Z)-12)

To a mixture of compounds (E)-11 and (Z)-11 (150 mg, $0.19 \mathrm{mmol})$ in $\mathrm{CH}_{2} \mathrm{Cl}_{2}(5 \mathrm{~mL})$ was added a solution of ammonia in $\mathrm{MeOH}(7 \mathrm{~N}, 20 \mathrm{~mL})$ at $0{ }^{\circ} \mathrm{C}$, and the mixture was stirred at $5{ }^{\circ} \mathrm{C}$ for 5 days. The volatiles were evaporated and the residue was purified via flash chromatography $\left(\mathrm{CH}_{2} \mathrm{Cl}_{2}\right.$ to $\left.\mathrm{CH}_{2} \mathrm{Cl}_{2}-\mathrm{MeOH}, 100: 2\right)$ to give a mixture of $(E)-\mathbf{1 2}$ and $(Z)-\mathbf{1 2}$ (120 mg, $0.17 \mathrm{mmol}, 91 \%$ ) as a colourless solid, which was used in the next step without further purification. $R_{\mathrm{f}}=0.36$ $\left(\mathrm{CH}_{2} \mathrm{Cl}_{2}-\mathrm{MeOH}, 100: 5\right)$.

${ }^{1} \mathrm{H}-\mathrm{NMR}\left(300 \mathrm{MHz}, \mathrm{C}^{2} \mathrm{HCl}_{3}\right.$ ) for $(E)-12$ and $(Z)-12$ (subscripts " $E$ " and " $Z$ " characterize respectively the ${ }^{1} \mathrm{H}$-NMR signals of $(E)-12$ and (Z)-12, which are respectively present in a $4: 1$ ratio): $\delta / \mathrm{ppm}=8.36\left(0.2 \mathrm{H}, \mathrm{s}, 2^{\prime}-\mathrm{H}_{Z}\right), 8.35\left(0.8 \mathrm{H}, \mathrm{s}, 2^{\prime}-\mathrm{H}_{E}\right), 7.91$ $\left(0.2 \mathrm{H}, \mathrm{s}, 8^{\prime}-\mathrm{H}_{Z}\right), 7.89\left(0.8 \mathrm{H}, \mathrm{s}, 8^{\prime}-\mathrm{H}_{E}\right), 6.07\left(1 \mathrm{H}, \mathrm{d}, J_{34,35}=1.8 \mathrm{~Hz}\right.$, $35-\mathrm{H}_{Z}$ and $\left.35-\mathrm{H}_{E}\right), 5.90\left(2 \mathrm{H}\right.$, br. s, $\left.-\mathrm{NH}_{2}\right), 5.54(0.8 \mathrm{H}, \mathrm{dd}$, $\left.J_{33,34}=6.2 \mathrm{~Hz}, J_{34,35}=1.9 \mathrm{~Hz}, 34-\mathrm{H}_{E}\right), 5.50\left(0.2 \mathrm{H}, \mathrm{dd}, J_{33,34}=\right.$ $\left.6.2 \mathrm{~Hz}, J_{34,35}=1.9 \mathrm{~Hz}, 34-\mathrm{H}_{Z}\right), 5.45\left(0.8 \mathrm{H}, \mathrm{dd}, J_{30,31}=15.3 \mathrm{~Hz}\right.$,
$\left.J_{22,30}=8.1 \mathrm{~Hz}, 30-\mathrm{H}_{E}\right), 5.36\left(0.8 \mathrm{H}, \mathrm{dd}, J_{30,31}=15.3 \mathrm{~Hz}, J_{31,32}=\right.$ $\left.6.8 \mathrm{~Hz}, 31-\mathrm{H}_{E}\right), 5.31-5.29\left(0.4 \mathrm{H}, \mathrm{m}, 31-\mathrm{H}_{Z}\right.$ and $\left.30-\mathrm{H}_{Z}\right), 4.97$ $\left(0.2 \mathrm{H}, \mathrm{dd}, J_{31,32}=4.7 \mathrm{~Hz}, J_{32,33}=2.9 \mathrm{~Hz}, 32-\mathrm{H}_{Z}\right), 4.94(0.8 \mathrm{H}, \mathrm{dd}$, $\left.J_{33,34}=6.3 \mathrm{~Hz}, J_{32,33}=3.1 \mathrm{~Hz}, 33-\mathrm{H}_{E}\right), 4.83\left(0.2 \mathrm{H}, \mathrm{dd}, J_{33,34}=6.3\right.$ $\left.\mathrm{Hz}, J_{32,33}=3.1 \mathrm{~Hz}, 33-\mathrm{H}_{Z}\right), 4.69\left(0.8 \mathrm{H}, \mathrm{dd}, J_{31,32}=6.8 \mathrm{~Hz}\right.$, $\left.J_{32,33}=2.9 \mathrm{~Hz}, 32-\mathrm{H}_{E}\right), 2.72-2.63\left(0.2 \mathrm{H}, \mathrm{m}, 22-\mathrm{H}_{Z}\right), 2.17-2.09$ $\left(0.8 \mathrm{H}, \mathrm{m}, 22-\mathrm{H}_{E}\right), 1.63\left(0.6 \mathrm{H}, \mathrm{s}, \mathrm{Me}_{2} \mathrm{C}_{Z}\right), 1.61\left(2.4 \mathrm{H}, \mathrm{s}, \mathrm{Me}_{2} \mathrm{C}_{E}\right)$, $1.40\left(3 \mathrm{H}, \mathrm{s}, \mathrm{Me}_{2} \mathrm{C}\right), 1.00\left(0.6 \mathrm{H}, \mathrm{d}, J_{22,29}=6.4 \mathrm{~Hz}, 22 R-\mathrm{Me}_{Z}\right), 0.96$ and $0.94\left(1.2 \mathrm{H}, 2 \mathrm{~s}, 8 \beta-\mathrm{Me}_{Z}\right.$ and $\left.14 \alpha-\mathrm{Me}_{Z}\right), 0.93(2.4 \mathrm{H}, \mathrm{s}$, $\left.8 \beta-\mathrm{Me}_{E}\right), 0.92\left(2.4 \mathrm{H}, \mathrm{s}, 14 \alpha-\mathrm{Me}_{E}\right), 0.89\left(2.4 \mathrm{H}, \mathrm{d}, J_{22,29}=6.4 \mathrm{~Hz}\right.$, $\left.22 R-\mathrm{Me}_{E}\right), 0.834(3 \mathrm{H}, \mathrm{s}, 4 \alpha-\mathrm{Me}), 0.799(3 \mathrm{H}, \mathrm{s}, 10 \beta-\mathrm{Me}), 0.779$

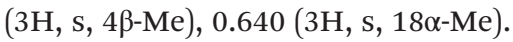

${ }^{13} \mathrm{C}-\mathrm{NMR}\left(75 \mathrm{MHz}, \mathrm{C}^{2} \mathrm{HCl}_{3}\right.$ ) for $(E)-12: \delta / \mathrm{ppm}=155.5,153.0$, $149.4,141.7,139.8,124.8,120.3$, 114.2, 90.8, 88.4, 85.0, 84.4, 56.1, 54.1, 50.4, 49.1, 44.9, 44.3, 42.1, 41.8, 41.7, 41.6, 40.5, $40.3,37.4,33.5,33.4,33.3,33.2,27.5,27.1,25.4,23.9,22.1$, 22.0, 21.7, 21.6, 20.9, 18.7, 16.6, 15.9 .

HRMS (ESI): $m / z[\mathrm{M}+\mathrm{H}]^{+}$, calcd for $\mathrm{C}_{43} \mathrm{H}_{65} \mathrm{~N}_{5} \mathrm{NaO}_{3}{ }^{+}$ 722.498 , found 722.497 .

\section{3,34-O-Isopropylidene adenosylhopane (13)}

To a stirred slurry of potassium azodicarboxylate $(90 \mathrm{mg}$, $0.46 \mathrm{mmol})$ in pyridine $(1 \mathrm{~mL})$ in a two-neck round bottom flask equipped with a condenser under $\mathrm{N}_{2}$ atmosphere was added a solution of $12(32 \mathrm{mg}, 0.046 \mathrm{mmol}$ ) in pyridine ( $3 \mathrm{~mL})$. The mixture was heated to reflux, and a solution of anhydrous acetic acid $(0.030 \mathrm{~mL}, 0.55 \mathrm{mmol})$ in pyridine (0.1 $\mathrm{mL})$ was carefully added dropwise. Each drop of acetic acid solution was added after the end of $\mathrm{N}_{2}$ evolution. The mixture was left under reflux until the yellow colour vanished. Another five portions of potassium azodicarboxylate and subsequent acetic acid were necessary to increase the conversion. The reaction was quenched with water, and extracted with dichloromethane three times. The combined organic phases were washed with brine and dried over anhydrous $\mathrm{Na}_{2} \mathrm{SO}_{4}$, filtered through cotton, and evaporated to dryness in vacuo. The crude product was further purified by flash chromatography $\left(\mathrm{CH}_{2} \mathrm{Cl}_{2}-\mathrm{MeOH} 100: 1\right.$ to $\left.100: 2\right)$ to yield the saturated product 13 (23 mg, 73\%). Compound 13 was isolated as a colourless solid. $R_{\mathrm{f}}=0.38\left(\mathrm{CH}_{2} \mathrm{Cl}_{2}-\mathrm{MeOH}, 100: 5\right)$.

M.p. $=256-257^{\circ} \mathrm{C} .[\alpha]_{\mathrm{D}}^{20}=+34\left(c 0.35, \mathrm{CHCl}_{3}\right)$.

${ }^{1} \mathrm{H}-\mathrm{NMR}\left(\mathrm{C}^{2} \mathrm{HCl}_{3}, 300 \mathrm{MHz}\right): \delta / \mathrm{ppm}=8.35\left(1 \mathrm{H}, \mathrm{s}, 2^{\prime}-\mathrm{H}\right)$, $7.89\left(1 \mathrm{H}, \mathrm{s}, 8^{\prime}-\mathrm{H}\right), 6.03\left(1 \mathrm{H}, \mathrm{dd}, J_{34,35}=2.4 \mathrm{~Hz}, 35-\mathrm{H}\right), 5.85(2 \mathrm{H}$, $\left.\mathrm{s},-\mathrm{NH}_{2}\right), 5.51\left(1 \mathrm{H}, J_{33,34}=6.5 \mathrm{~Hz}, J_{34,35}=2.4 \mathrm{~Hz}, 34-\mathrm{H}\right), 4.80$ $\left(1 \mathrm{H}, \mathrm{dd}, J_{33,34}=6.5 \mathrm{~Hz}, J_{32,33}=3.5 \mathrm{~Hz}, 33-\mathrm{H}\right), 4.15(1 \mathrm{H}$, ddd, $\left.J_{31 \mathrm{a}, 32}=7.4 \mathrm{~Hz}, J_{31 \mathrm{~b}, 32}=6.5 \mathrm{~Hz}, J_{32,33}=3.5 \mathrm{~Hz}, 32-\mathrm{H}\right), 1.60$ and $1.38\left(2 \times 3 \mathrm{H}, 2 \mathrm{~s}, \mathrm{Me}_{2} \mathrm{C}\right), 0.928(3 \mathrm{H}, \mathrm{s}, 8 \beta-\mathrm{Me}), 0.921(3 \mathrm{H}, \mathrm{S}$, $14 \alpha-\mathrm{Me}), 0.83(3 \mathrm{H}, \mathrm{d}, J=6.2 \mathrm{~Hz}, 22-\mathrm{Me}), 0.834(3 \mathrm{H}, \mathrm{s}, 4 \alpha-\mathrm{Me})$, $0.800(3 \mathrm{H}, \mathrm{s}, 10 \beta-\mathrm{Me}), 0.779(3 \mathrm{H}, \mathrm{s}, 4 \beta-\mathrm{Me}), 0.656(3 \mathrm{H}, \mathrm{s}$, $18 \alpha-\mathrm{Me})$.

${ }^{13} \mathrm{C}-\mathrm{NMR}$ data $\left(\mathrm{C}^{2} \mathrm{HCl}_{3}, 75 \mathrm{MHz}\right): \delta / \mathrm{ppm}=155.4\left(\mathrm{C}-6^{\prime}\right)$, 153.0 (C-2'), 139.8 (C-8'), 149.4 (C-4'), 120.3 (C-5'), 114.4 $\left(\mathrm{CMe}_{2}\right), 90.5$ (C-35), 87.7 (C-32), 84.3 (C-34), 84.0 (C-33), 56.1 (C-5), 54.4 (C-17), 50.4 (C-9), 49.3 (C-13), 45.7 (C-21), 44.3 (C-18), 42.1 (C-3), 41.8 (C-14), 41.7 (C-8), 41.5 (C-19), 40.3 (C-1), 37.4 (C-10), 36.4 (C-22), 33.6 (C-15), 33.4 (C-23), 33.2 and 33.1 
(C-4 and C-7), 31.4 (C-30), 30.0 (C-31), 27.5 (C-20), 23.9 (C-12), 22.7 (C-16), 21.6 (C-24), 20.9 (C-11), 20.0 (C-29), 18.7 (C-2 and C-6), 16.6 and 16.5 (C-26 and C-27), 15.9 and 15.8 (C-25 and C-28).

HRMS (ESI): $m / z[\mathrm{M}+\mathrm{H}]^{+}$, calcd for $\mathrm{C}_{43} \mathrm{H}_{67} \mathrm{~N}_{5} \mathrm{NaO}_{3}{ }^{+}$ 724.514 , found 724.512 .

\section{[30,31- $\left.{ }^{2} \mathbf{H}_{2}\right]-33,34-O$-Isopropylidene adenosylhopane (13-D)}

Compound 12 (51 mg, $0.073 \mathrm{mmol}$ ) was dissolved in a mixture of $\mathrm{CH}_{3} \mathrm{O}^{2} \mathrm{H}-\mathrm{C}^{2} \mathrm{HCl}_{3}(1: 2)$ under an atmosphere of $\mathrm{N}_{2}$ for $\mathrm{H}^{-}{ }^{2} \mathrm{H}$ exchange. After $5 \mathrm{~min}$ standing, the solvents were carefully evaporated under vacuum. The same procedure was repeated three times, and the $\mathrm{N}$-deuteriated intermediate 12-D was carefully dried overnight under vacuum in the presence of $\mathrm{P}_{2} \mathrm{O}_{5}$. Compound 13-D was prepared following the procedure described for the synthesis of natural abundance 13 using potassium azodicarboxylate ( $850 \mathrm{mg}, 43.8 \mathrm{mmol}$ ) and $\mathrm{CH}_{3} \mathrm{COO}^{2} \mathrm{H}$ ( $98 \%$ isotope abundance, $3.3 \mathrm{~mL}, 56.9 \mathrm{mmol}$ ) to generate deuteriated diimide in situ. Compound 13-D (31 mg, 60\%) was isolated as a colourless solid with unreacted starting material 12 $(8.6 \mathrm{mg}, 17 \%)$ by TLC $\left(\mathrm{CH}_{2} \mathrm{Cl}_{2}-\mathrm{MeOH}, 100: 5, R_{\mathrm{f}}=0.38\right)$. Deuterium content of 13-D was determined from HRMS (ESI) spectrum by evaluating the relative intensities of the $\mathrm{m} / \mathrm{z} 724,725$ and 726 peaks corresponding to each isotopomer: natural abundance adenosylhopane (8\%), monodeuteriated adenosylhopane $(32 \%)$ and bisdeuteriated adenosylhopane $(60 \%)$, trisdeuteriated adenosylhopane (0\%).

${ }^{1} \mathrm{H}-\mathrm{NMR}\left(\mathrm{C}^{2} \mathrm{HCl}_{3}, 600 \mathrm{MHz}\right): \delta / \mathrm{ppm}=8.35\left(1 \mathrm{H}, \mathrm{s}, 2^{\prime}-\mathrm{H}\right)$, $7.90\left(1 \mathrm{H}, \mathrm{s}, 8^{\prime}-\mathrm{H}\right), 6.03\left(1 \mathrm{H}, \mathrm{d}, J_{34,35}=2.4 \mathrm{~Hz}, 35-\mathrm{H}\right), 5.92(2 \mathrm{H}, \mathrm{s}$, $\left.-\mathrm{NH}_{2}\right), 5.51\left(1 \mathrm{H}, \mathrm{ddd}, J_{33,34}=6.4 \mathrm{~Hz}, J_{34,35}=2.4 \mathrm{~Hz}, J_{32,34}=\right.$ $1.2 \mathrm{~Hz}, 34-\mathrm{H}), 4.80\left(1 \mathrm{H}\right.$, ddd, $J_{33,34}=6.4 \mathrm{~Hz}, J_{32,33}=3.5 \mathrm{~Hz}$, $\left.J_{31,33}=1.2 \mathrm{~Hz}, 33-\mathrm{H}\right), 4.15(1 \mathrm{H}$, dd for the major isotopomer, $\left.J_{31,32}=7.2 \mathrm{~Hz}, J_{32,33}=3.5 \mathrm{~Hz}, 32-\mathrm{H}\right), 1.60$ and $1.38(2 \times 3 \mathrm{H}, 2 \mathrm{~s}$,

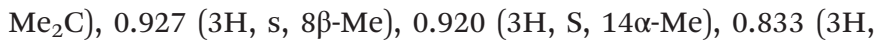

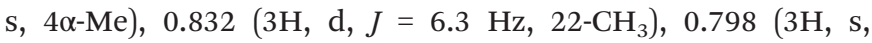
$10 \beta-\mathrm{Me}), 0.778$ (3H, s, $4 \beta-\mathrm{Me}), 0.655$ (3H, s, 18 $\alpha-\mathrm{Me})$.

${ }^{13} \mathrm{C}-\mathrm{NMR}$ data $\left(\mathrm{C}^{2} \mathrm{HCl}_{3}, 150 \mathrm{MHz}\right): \delta / \mathrm{ppm}=155.5\left(\mathrm{C}-6^{\prime}\right)$, 152.9 (C-2'), 139.8 (C-8'), 149.4 (C-4'), 120.3 (C-5'), 114.4 $\left(\mathrm{CMe}_{2}\right), 90.5$ (C-35), 87.63 and 87.60 (C-32, $\beta$-shift induced by deuterium at C-31), 84.3 (C-34), 84.0 (C-33), 56.1 (C-5), 54.3 (C-17), 50.4 (C-9), 49.2 (C-13), 45.7 (C-21), 44.3 (C-18), 42.1 (C-3), 41.8 (C-14), 41.6 (C-8), 41.5 (C-19), 40.3 (C-1), 37.4 (C-10), $36.35,36.28$ and 36.25 (C-22, $\beta$-shifts induced by deuterium at C-30), 33.6 (C-15), 33.4 (C-23), 33.2 and 33.1 (C-4 and C-7), missing signal (C-30 bearing a deuterium), missing signal (C-31 bearing a deuterium), 27.5 (C-20), 23.9 (C-12), 22.7 (C-16), 21.6 (C-24), 20.9 (C-11), 20.0 (C-29), 18.7 (C-2 and C-6), 16.6 and 16.5 (C-26 and C-27), 15.9 and 15.8 (C-25 and C-28).

HRMS (ESI): $m / z[\mathrm{M}+\mathrm{H}]^{+}$, calcd for $\mathrm{C}_{43} \mathrm{H}_{65} \mathrm{D}_{2} \mathrm{~N}_{5} \mathrm{NaO}_{3}{ }^{+}$ 726.526 , found 726.523 .

\section{Adenosylhopane (2)}

A solution of $13(6.3 \mathrm{mg}, 9 \mu \mathrm{mol})$ and TFA $(2 \mathrm{~mL})$ in $\mathrm{CHCl}_{3}-$ $\mathrm{MeOH}(2: 1,5 \mathrm{~mL})$ in a round bottomed flask was shaken under reduced pressure (450-500 mbar) at $0{ }^{\circ} \mathrm{C}$ for $2 \mathrm{~h} 30$ (rotary evaporator). When starting material could no more be detected by TLC, the reaction mixture was evaporated to dryness and the residue was purified by column chromatography over silica gel $(63-200 \mu \mathrm{m})\left(\mathrm{CHCl}_{3}-\mathrm{MeOH}-\mathrm{NH}_{4} \mathrm{OH}\right.$, $100: 2: 0.5$ to $100: 5: 0.5$ to $100: 7.5: 0.5)$ to afford adenosylhopane 2 as a colourless solid ( $5.3 \mathrm{mg}, 8 \mu \mathrm{mol} 90 \%) . R_{\mathrm{f}}=0.09$ $\left(\mathrm{CH}_{2} \mathrm{Cl}_{2}-\mathrm{MeOH} 100: 5\right) .[\alpha]_{\mathrm{D}}^{20}=+34$ (c 0.3, THF).

${ }^{1} \mathrm{H}$-NMR $\left(\left({ }^{2} \mathrm{H}_{5}\right)\right.$ pyridine, $\left.600 \mathrm{MHz}\right): \delta(\mathrm{ppm})=8.77(1 \mathrm{H}, \mathrm{s}$, $2 '-\mathrm{H}), 8.61\left(1 \mathrm{H}, \mathrm{s}, 8^{\prime}-\mathrm{H}\right), 8.29\left(2 \mathrm{H}, \mathrm{s},-\mathrm{NH}_{2}\right), 7.74\left(1 \mathrm{H}, \mathrm{d}, J_{34, \mathrm{OH}}=\right.$ $5.5 \mathrm{~Hz}, 34-\mathrm{OH}), 7.04\left(1 \mathrm{H}, \mathrm{d}, J_{33, \mathrm{OH}}=5.8 \mathrm{~Hz}, 33-\mathrm{OH}\right), 6.72(1 \mathrm{H}$, $\left.\mathrm{d}, J_{34,35}=4.4 \mathrm{~Hz}, 35-\mathrm{H}\right), 5.43(1 \mathrm{H}$, pseudo q, $J=4.7 \mathrm{~Hz}, 34-\mathrm{H})$, $4.77(1 \mathrm{H}$, pseudo q, $J=5.2 \mathrm{~Hz}, 33-\mathrm{H}), 4.56(1 \mathrm{H}$, pseudo $\mathrm{dt}, J=$ $8.4 \mathrm{~Hz}, J=4.9 \mathrm{~Hz}, 32-\mathrm{H}), 2.13\left(1 \mathrm{H}, \mathrm{m}, 31-\mathrm{H}_{\mathrm{a}}\right), 1.96(1 \mathrm{H}, \mathrm{m}$, $\left.31-\mathrm{H}_{\mathrm{b}}\right), 1.79\left(2 \mathrm{H}, \mathrm{m}, 30-\mathrm{H}_{\mathrm{a}}\right.$ and $\left.20-\mathrm{H}_{\mathrm{a}}\right), 1.73(1 \mathrm{H}, \mathrm{m}, 21-\mathrm{H})$, $0.994(3 \mathrm{H}, \mathrm{d}, J=6.3 \mathrm{~Hz}), 0.959(3 \mathrm{H}, \mathrm{s}, 8 \beta-\mathrm{Me}), 0.948(3 \mathrm{H}, \mathrm{s}$,

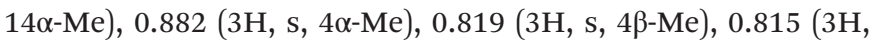

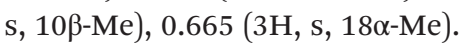

${ }^{13} \mathrm{C}-\mathrm{NMR}\left(\left({ }^{2} \mathrm{H}_{5}\right)\right.$ pyridine, $\left.150 \mathrm{MHz}\right): \delta(\mathrm{ppm})=157.6\left(\mathrm{C}-6^{\prime}\right)$, 153.8 (C-2'), 150.6 (C-4'), 140.0 (C-8'), 121.3 (C-5'), 90.0 (C-35), 85.2 (C-32), 75.24 and 75.16 (C-33 and C-34), 54.6 (C-17), 56.4 (C-5), 50.7 (C-9), 49.6 (C-13), 46.4 (C-21), 44.5 (C-18), 42.3(C-3), 42.0 (C-14), 41.9 (C-8), 41.8 (C-19), 40.5 (C-1), 37.6 (C-10), 36.9 (C-22), 34.0 (C-15), 33.6 (C-7 and C-23), 33.4 (C-4), 32.3 (C-30), 31.0 (C-31), 27.9 (C-20), 24.2 (C-12), 23.0 (C-16), 21.8 (C-24), 21.2 (C-11), 20.4 (C-29), 19.0 (C-2 and C-6), 16.8 and 16.7 (C-26 and C-27), 16.1 and 16.0 (C-25 and C-28).

HRMS (ESI): $m / z[\mathrm{M}+\mathrm{H}]^{+}$, calcd for $\mathrm{C}_{40} \mathrm{H}_{64} \mathrm{~N}_{5} \mathrm{O}_{3}{ }^{+}$662.501, found 662.500 .

\section{(30,31- $\left.{ }^{2} \mathbf{H}_{2}\right)$ Adenosylhopane (2-D)}

Deprotection of 13-D (9.3 mg, $13.2 \mu \mathrm{mol})$ by TFA $(3 \mathrm{~mL})$ in $\mathrm{CHCl}_{3}-\mathrm{MeOH}(2: 1,7 \mathrm{~mL})$ following procedure D afforded deuteriated adenosylhopane 2-D (7.7 mg, $11.6 \mu \mathrm{mol}, 90 \%) . R_{\mathrm{f}}=$ 0.09 (DCM-MeOH $100: 5$ ). Deuterium content of 2-D was calculated from HRMS (ES) spectrum: natural abundance adenosylhopane $8 \%$; monodeuteriated adenosylhopane $32 \%$; bisdeuteriated adenosylhopane $60 \%$; trisdeuteriated adenosylhopane $0 \%$.

${ }^{1} \mathrm{H}-\mathrm{NMR}\left(\left({ }^{2} \mathrm{H}_{5}\right)\right.$ pyridine, $\left.600 \mathrm{MHz}\right): \delta(\mathrm{ppm})=8.72(1 \mathrm{H}, \mathrm{s}$, $\left.2^{\prime}-\mathrm{H}\right), 8.60\left(1 \mathrm{H}, \mathrm{s}, 8^{\prime}-\mathrm{H}\right), 8.28\left(2 \mathrm{H}, \mathrm{s},-\mathrm{NH}_{2}\right), 7.73\left(1 \mathrm{H}, \mathrm{d}, J_{34, \mathrm{OH}}=\right.$ $5.1 \mathrm{~Hz}, 34-\mathrm{OH}), 7.03\left(1 \mathrm{H}, \mathrm{d}, J_{33, \mathrm{OH}}=5.6 \mathrm{~Hz}, 33-\mathrm{OH}\right), 6.72(1 \mathrm{H}$, $\left.\mathrm{d}, J_{34,35}=4.4 \mathrm{~Hz}, 35-\mathrm{H}\right), 5.43(1 \mathrm{H}$, pseudo q, $J=4.3 \mathrm{~Hz}, 34-\mathrm{H})$, 4.77 (1H, pseudo q, $J=5.0 \mathrm{~Hz}, 33-\mathrm{H}), 4.57-4.54(1 \mathrm{H}, \mathrm{m}, 32-\mathrm{H})$, $2.11\left(1 \mathrm{H}, \mathrm{dd}, J_{31 \mathrm{a}, 32}=8.3 \mathrm{~Hz}, J_{30 \mathrm{~b}, 31 \mathrm{a}}=4.6 \mathrm{~Hz}, 31-\mathrm{H}_{\mathrm{a}}\right), 1.93$ $\left(1 \mathrm{H}\right.$, pseudo $\left.\mathrm{t}, J_{31 \mathrm{~b}, 32}=J_{30 \mathrm{a}, 31 \mathrm{~b}}=5.0 \mathrm{~Hz}, 31-\mathrm{H}_{\mathrm{b}}\right), 1.82-1.71$ $\left(2.7 \mathrm{H}, \mathrm{m}, 30-\mathrm{H}_{\mathrm{a}}, 20-\mathrm{H}_{\mathrm{a}}\right.$ and $21-\mathrm{H}$ of isotopomer resulting from deuteriation of major isomer $\boldsymbol{E}-12), 1.75-1.72(1 \mathrm{H}, \mathrm{m}, 21-\mathrm{H})$, $0.993(3 \mathrm{H}, \mathrm{d}, J=6.3 \mathrm{~Hz}), 0.961(3 \mathrm{H}, \mathrm{s}, 8 \beta-\mathrm{Me}), 0.949(3 \mathrm{H}, \mathrm{s}$, $14 \alpha-\mathrm{Me}), 0.883$ (3H, s, $4 \alpha-\mathrm{Me}), 0.820$ (3H, s, $4 \beta-\mathrm{Me}), 0.816(3 \mathrm{H}$,

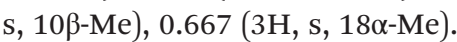

${ }^{13} \mathrm{C}-\mathrm{NMR}\left(\left({ }^{2} \mathrm{H}_{5}\right)\right.$ pyridine, $\left.150 \mathrm{MHz}\right): \delta(\mathrm{ppm})=157.6\left(\mathrm{C}-6^{\prime}\right)$, 153.8 (C-2'), 150.6 (C-4'), 140.0 (C-8'), $121.3\left(\mathrm{C}-5^{\prime}\right), 90.0$ (C-35), 85.20 and 85.15 (C-32, $\beta$-shift induced by deuterium at C-31), 75.21 and 75.15 (C-33 and C-34), 54.6 (C-17), 56.4 (C-5), 50.7 (C-9), 49.6 (C-13), 46.4 (C-21), 44.5 (C-18), 42.3(C-3), 42.0 (C-14), 41.9 (C-8), 41.8 (C-19), 40.5 (C-1), 37.6 (C-10), 36.90, 
36.86 and 36.81 (C-22, $\beta$-shifts induced by deuterium at C-30), 33.9 (C-15), 33.6 (C-7 and C-23), 33.4 (C-4), missing signal at ca. 32.3 (C-30 bearing a deuterium), missing signal at ca. 31.0 (C-31 bearing a deuterium), 27.9 (C-20), 24.2 (C-12), 23.0 (C-16), 21.8 (C-24), 21.2 (C-11), 20.3 (C-29), 19.0 (C-2 and C-6), 16.8 and 16.7 (C-26 and C-27), 16.1 and 16.0 (C-25 and C-28).

HRMS (ESI): $m / z[\mathrm{M}+\mathrm{H}]^{+}$, calcd for $\mathrm{C}_{40} \mathrm{H}_{62}{ }^{2} \mathrm{H}_{2} \mathrm{~N}_{5} \mathrm{O}_{3}{ }^{+}$ 664.513, found 664.513 .

\section{Adenosylhopane acetates (14a-c)}

Adenosylhopane 2 (1.8 mg) was acetylated overnight at room temperature with a mixture of acetic anhydride and pyridine $(0.3 \mathrm{~mL}, \mathrm{v} / \mathrm{v}, 1 / 2)$. Reagents were removed under vacuum. The resulting residue was purified by preparative thin layer chromatography $\left(\mathrm{CH}_{2} \mathrm{Cl}_{2}-\mathrm{MeOH}, 100: 5\right)$ to afford adenosylhopane diacetate 14a $\left(0.4 \mathrm{mg}, R_{\mathrm{f}}=0.30\right)$, triacetate $14 \mathrm{~b}\left(0.6 \mathrm{mg}, R_{\mathrm{f}}=\right.$ $0.38)^{1 a, b}$ and tetraacetate $14 \mathrm{c}\left(0.8 \mathrm{mg}, R_{\mathrm{f}}=0.66\right)$.

Adenosylhopane diacetate (14a). ${ }^{1} \mathrm{H}-\mathrm{NMR} \quad(300 \mathrm{MHz}$, $\left.\mathrm{C}^{2} \mathrm{HCl}_{3}\right): \delta / \mathrm{ppm}=8.30$ and $7.95\left(2 \times 1 \mathrm{H}, 2 \mathrm{~s}, 2^{\prime}-\mathrm{H}\right.$ and $\left.8^{\prime}-\mathrm{H}\right)$, $6.68\left(2 \mathrm{H}\right.$, br. s, $\left.-\mathrm{NH}_{2}\right), 6.14(1 \mathrm{H}, \mathrm{d}, J=5.5 \mathrm{~Hz}, 35-\mathrm{H}), 5.87(1 \mathrm{H}$, $\mathrm{dd}, J=5.7,5.5 \mathrm{~Hz}, 34-\mathrm{H}), 5.38(1 \mathrm{H}, \mathrm{dd}, J=5.5,4.5 \mathrm{~Hz}, 33-\mathrm{H})$, 4.15 (1H, td, $J=8.4,4.3 \mathrm{~Hz}, 32-\mathrm{H}), 2.14$ (3H, s, $\left.\mathrm{CH}_{3} \mathrm{COO}-\right), 2.06$ ( $3 \mathrm{H}, \mathrm{s}, \mathrm{CH}_{3} \mathrm{COO}-$ ), 0.94 (9H, m, $8 \beta-\mathrm{Me}, 14 \alpha-\mathrm{Me}$ and $22 R-\mathrm{Me}$ ),

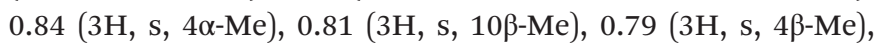
0.68 (3H, s, $18 \alpha-\mathrm{Me})$.

MS (EI, direct inlet, positive mode $70 \mathrm{eV}): m / z=746\left(\mathrm{M}^{+}\right.$, 9\%), $686\left(\mathrm{M}^{+}-\mathrm{AcOH}, 6 \%\right), 626\left(\mathrm{M}^{+}-2 \mathrm{AcOH}, 24 \%\right), 595$ (6\%), 538 (15\%), 491 (5\%), 389 (17\%), $367\left(\mathrm{M}^{+}-\mathrm{CH}_{2} \mathrm{CO}\right.$ - side chain, 9\%), 191 (ring C cleavage, 10\%), 136 ([adenine $+\mathrm{H}]^{+}$, $100 \%)$.

Adenosylhopane triaacetate (14b). ${ }^{1} \mathrm{H}-\mathrm{NMR} \quad(300 \mathrm{MHz}$, $\left.\mathrm{C}^{2} \mathrm{HCl}_{3}\right): \delta / \mathrm{ppm}=8.87\left(1 \mathrm{H}, \mathrm{s}, \mathrm{NHCOCH}_{3}\right), 8.69$ and 8.06 $\left(2 \times 1 \mathrm{H}, 2 \mathrm{~s}, 2^{\prime}-\mathrm{H}\right.$ and $\left.8^{\prime}-\mathrm{H}\right), 6.14(2 \mathrm{H}, \mathrm{d}, J=5.5 \mathrm{~Hz}, 35-\mathrm{H}), 5.94$ $(1 \mathrm{H}, \mathrm{dd}, J=J=5.5 \mathrm{~Hz}, 34-\mathrm{H}), 5.42(1 \mathrm{H}, \mathrm{dd}, J=5.5,4.5 \mathrm{~Hz}$, $33-\mathrm{H}), 4.17(1 \mathrm{H}, \mathrm{td}, J=8.4,4.3 \mathrm{~Hz}, 32-\mathrm{H}), 2.60(3 \mathrm{H}, \mathrm{s}$, $\mathrm{CH}_{3} \mathrm{CONH}-$ ), 2.15 (3H, s, $\mathrm{CH}_{3} \mathrm{COO}-$ ), 2.06 (3H, s, CH $\mathrm{H}_{3} \mathrm{COO}-$ ),

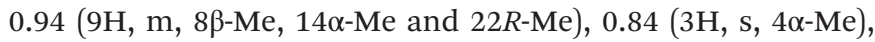

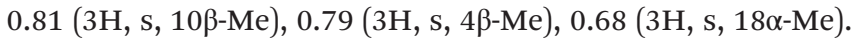

MS (EI, direct inlet, positive mode $70 \mathrm{eV}): \mathrm{m} / z=788\left(\mathbf{M}^{+}\right.$, 2\%), $610\left(\mathrm{M}^{+}-N, N\right.$-acetyladenine, 4\%), 595 (ring C cleavage, 2\%), 491 (1\%), 389 (6\%), $367\left(\mathrm{M}^{+}-\mathrm{CH}_{2} \mathrm{CO}\right.$ - side chain, 4\%), 191 (ring C cleavage, 11\%), 178 ([N-acetyladenine $\left.+\mathrm{H}]^{+}, 100 \%\right)$.

Adenosylhopane tetraacetate (14c). ${ }^{1} \mathrm{H}-\mathrm{NMR}(300 \mathrm{MHz}$, $\left.\mathrm{C}^{2} \mathrm{HCl}_{3}\right): \delta / \mathrm{ppm}=8.97$ and $8.21\left(2 \times 1 \mathrm{H}, 2 \mathrm{~s}, 2^{\prime}-\mathrm{H}\right.$ and $\left.8^{\prime}-\mathrm{H}\right)$, $6.18(2 \mathrm{H}, \mathrm{d}, J=5.5 \mathrm{~Hz}, 35-\mathrm{H}), 5.96(1 \mathrm{H}, \mathrm{dd}, J=J=5.5 \mathrm{~Hz}, 34-$ $\mathrm{H}), 5.42(1 \mathrm{H}, \mathrm{dd}, J=5.5,4.5 \mathrm{~Hz}, 33-\mathrm{H}), 4.21-4.17(1 \mathrm{H}, \mathrm{m}, 32-$ $\mathrm{H}), 2.37$ (6H, s, $\left.2 \times \mathrm{CH}_{3} \mathrm{CONH}-\right), 2.16\left(3 \mathrm{H}, \mathrm{s}, \mathrm{CH}_{3} \mathrm{COO}-\right), 2.09$ $\left(3 \mathrm{H}, \mathrm{s}, \mathrm{CH}_{3} \mathrm{COO}-\right)$, 0.94 (6H, br. s, $8 \beta-\mathrm{Me}$ and $\left.14 \alpha-\mathrm{Me}\right), 0.94$ $(3 \mathrm{H}, \mathrm{d}, J=6.1 \mathrm{~Hz}, 22 R-\mathrm{Me}), 0.84(3 \mathrm{H}, \mathrm{s}, 4 \alpha-\mathrm{Me}), 0.81(3 \mathrm{H}, \mathrm{s}$,

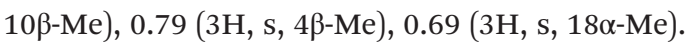

MS (EI, direct inlet, positive mode $70 \mathrm{eV}): \mathrm{m} / \mathrm{z}=830\left(\mathrm{M}^{+}\right.$, $0.3 \%), 788\left(\mathrm{M}^{+}-\mathrm{CH}_{2} \mathrm{CO}\right), 662(1 \%), 610\left(\mathrm{M}^{+}-\mathrm{CH}_{2} \mathrm{CO}-N_{,} N^{-}\right.$ diacetyladenine, 8\%), 595 (ring $\mathrm{C}$ cleavage $-\mathrm{CH}_{2} \mathrm{CO}, 5 \%$ ), 491 (3\%), 389 (16\%), $367\left(\mathrm{M}^{+}-\mathrm{CH}_{2} \mathrm{CO}\right.$ - side chain, 8\%), 191 (ring C cleavage, 20\%), 178 (100\%).
Culture of $M$. organophilum and preparation of the cell-free system

Methylobacterium organophilum DSM 760 was grown on a modified medium of Hestrin and Schramm ${ }^{36}(6 \times 500 \mathrm{~mL}$, yeast extract $5 \mathrm{~g} \mathrm{~L}^{-1}$, bactopeptone $5 \mathrm{~g} \mathrm{~L}^{-1}$, glucose $1 \mathrm{~g} \mathrm{~L}^{-1}$, anhydrous citric acid $1.04 \mathrm{~g} \mathrm{~L}^{-1}, \mathrm{Na}_{2} \mathrm{HPO}_{4} 2.7 \mathrm{~g} \mathrm{~L}^{-1}, \mathrm{pH}=6.8$ ) in $2 \mathrm{~L}$ Erlenmeyer flasks on a rotatory shaker $(200 \mathrm{rpm})$ at $30{ }^{\circ} \mathrm{C}$. Optical densities of the bacterial cultures were measured at $595 \mathrm{~nm}$ on a Genesys $10 \mathrm{UV}$ spectrophotometer using $1 \mathrm{~cm}$ in length and $1 \mathrm{~mL}$ volume cuvettes. The cells were harvested before the end of the exponential growth phase (OD $\sim 0.6$ ) by centrifugation ( $8000 \mathrm{rpm}, 10 \mathrm{~min}$ ), and then washed with buffer either a sodium phosphate buffer $(50 \mathrm{mM}$ $\mathrm{NaH}_{2} \mathrm{PO}_{4}-\mathrm{Na}_{2} \mathrm{HPO}_{4}, 0.5 \mathrm{mM}, \mathrm{MgCl}_{2}, 1 \mathrm{mM}$ dithiothreitol, $\mathrm{pH}$ 7.5) or a triethylamine buffer $(0.1 \mathrm{M}$ triethylamine, $0.5 \mathrm{mM}$ $\mathrm{MgCl}_{2}, 1 \mathrm{mM}$ dithiothreitol, $\mathrm{pH}$ 7.5). After centrifugation (8 $000 \mathrm{rpm}, 10 \mathrm{~min}$ ), the cell pellet ( $3 \mathrm{~g}$ ) was suspended in the buffer $(15 \mathrm{~mL})$ and disrupted by sonication at $0{ }^{\circ} \mathrm{C}$ in a melting ice bath using a Branson SONIFIER B-30 $(8 \times 40 \mathrm{~s}$ with 3 min pause at $0{ }^{\circ} \mathrm{C}, 60 \%$ pulsed duty cycle, output control: 6 ). The crude cell-free system was centrifuged $(10000 \mathrm{rpm}$, $10 \mathrm{~min}$ ). The pellet was freeze-dried to recover bacteriohopanetetrol of natural abundance, and the supernatant was directly used for the incubation deuterium labelled adenosylhopane.

\section{Conversion of deuteriated adenosylhopane into bacteriohopanetetrol by a crude cell-free system from M. organophilum}

A solution of deuteriated adenosylhopane 2-D (200 $\mu \mathrm{g})$ in THF $(500 \mu \mathrm{L})$ was added to the supernatant $(5 \mathrm{~mL})$ described above in a glass screw cap vial. After addition of a solution of NADPH $(1.5 \mathrm{mg})$ in water $(100 \mu \mathrm{L})$, the sample was incubated at $30^{\circ} \mathrm{C}$ by shaking $(200 \mathrm{rpm})$. An additional portion of the cofactor solution $(100 \mu \mathrm{L})$ was added after $4 \mathrm{~h}$ incubation and the sample was incubated for another $20 \mathrm{~h}$. After lyophilisation, the residue was directly acetylated overnight at room temperature with $\mathrm{Ac}_{2} \mathrm{O}$-pyridine $(1: 2 \mathrm{v} / \mathrm{v}, 3.9 \mathrm{~mL})$. The reaction mixture was filtered over cotton and washed with toluene $(3 \times$ $2 \mathrm{~mL})$ and $\mathrm{CH}_{2} \mathrm{Cl}_{2}(3 \times 2 \mathrm{~mL})$. The combined filtrates were concentrated in vacuo, and the residue was subjected to preparative TLC (cyclohexane-ethyl acetate, 3:7) to give an apolar fraction $\left(R_{\mathrm{f}}>0.7\right)$ containing diploptene, diplopterol and acetylated bacteriohopanetetrol. This less polar fraction was further separated by TLC (cyclohexane-ethyl acetate, 5:1), yielding pure bacteriohopanetetrol tetraacetate $\left(0.16<R_{\mathrm{f}}<\right.$ 0.20), which was analysed by GC-EIMS.

\section{Isolation of natural abundance bacteriohopanetetrol from M. organophilum or from cell-free system unbroken cells and cell debris pellet}

The freeze-dried material (unbroken cells and large cell debris) recovered after the centrifugation yielding the supernatant used for the incubations was extracted with $\mathrm{CHCl}_{3}-\mathrm{CH}_{3} \mathrm{OH}$ $(2: 1, \mathrm{v} / \mathrm{v})$ three times under reflux. The combined extracts were brought to dryness, acetylated with $\mathrm{Ac}_{2} \mathrm{O}$-pyridine $(1: 2$, 
$\mathrm{v} / \mathrm{v}$ ) and the excess of reagents was evaporated in vacuo. The residue was separated by preparative TLC (silica gel, cyclohexane-ethyl acetate, $3: 7)$ to give an apolar fraction $\left(R_{\mathrm{f}}>0.7\right)$ containing diploptene, diplopterol, and acetylated bacteriohopanetetrol. This mixture was further separated by preparative TLC (silica gel, cyclohexane-ethyl acetate, $5: 1$ ), yielding pure bacteriohopanetetrol tetraacetate $\left(0.16<R_{\mathrm{f}}<0.20\right)$.

\section{Acknowledgements}

This work was supported by a grant from the Foundation "Frontier Research in Chemistry" (Strasbourg, France). WL acknowledges financial support from the China Scholarship Council and the French embassy in Beijing. The authors express their gratitude to E. Motsch and Dr P. Schaeffer for EIMS and GC-EIMS measurements, Dr L. Allouche, B. Vincent and J.D. Sauer for NMR measurements and R. Carrière and Dr H. Nierengarten for ES-HRMS measurements.

\section{References}

1 (a) S. Neunlist and M. Rohmer, Biochem. J., 1985, 228, 769; (b) S. Neunlist, P. Bisseret and M. Rohmer, Eur. J. Biochem., 1988, 171, 245; (c) M. Seemann, P. Bisseret, J. P. Tritz, A. B. Hooper and M. Rohmer, Tetrahedron Lett., 1999, 40, 1681; (d) J. M. Bravo, M. Perzl, T. Härtner, E. L. Kannenberg and M. Rohmer, Eur. J. Biochem., 2001, 268, 1323; (e) M. Eickhoff, D. Birgel, H. M. Talbot, J. Peckman and A. Kappler, Geobiology, 2013, 11, 268.

2 H. M. Talbot, M. Rohmer and P. Farrimond, Rapid Commun. Mass Spectrom., 2007, 21, 880.

3 (a) M. P. Cooke, H. M. Talbot and P. Farrimond, Org. Geochem., 2008, 39, 1347; (b) M. P. Cooke, H. M. Talbot and T. Wagner, Org. Geochem., 2008, 39, 965; (c) Y. Xu, M. P. Cooke, H. M. Talbot and M. J. Simpson, Org. Geochem., 2008, 40, 79.

4 A. D. Selver, H. M. Talbot, O. Gustafsson, S. Boult and B. E. van Dongen, Org. Geochem., 2012, 51, 63.

5 T. Wagner, W. Kallweit, H. M. Talbot, G. Mollenhauer, A. Boom and T. Zabel, Org. Geochem., 2014, 67, 85.

6 P. Bisseret and M. Rohmer, J. Org. Chem., 1989, 54, 2958.

7 S. Neunlist and M. Rohmer, J. Chem. Soc., Chem. Commun., 1988, 830 .

8 G. Flesch and M. Rohmer, Eur. J. Biochem., 1988, 175, 405.

9 M. Rohmer, B. Sutter and H. Sahm, J. Chem. Soc., Chem. Commun., 1989, 1471.

10 M. Rohmer, Pure Appl. Chem., 1993, 65, 1293.

11 A. S. Bradley, A. Pearson, J. P. Sáenz and C. J. Marx, Org. Geochem., 2010, 41, 1075.

12 P. V. Welander, D. M. Doughty, C. H. Wu, S. Mehay, R. Summons and D. K. Newman, Geobiology, 2012, 10, 163.
13 W. Liu, E. Sakr, P. Schaeffer, H. M. Talbot, J. Donisi, T. Härtner, E. Kannenberg, E. Takano and M. Rohmer, ChemBioChem, 2014, 15, 2156.

14 P. Stampf, PhD Thesis, Université de Haute Alsace, Mulhouse, France, 1992.

15 T. Duvold and M. Rohmer, Tetrahedron, 1999, 55, 9847.

16 W. D. Pan, PhD Thesis, Université de Paris VI, Paris, France, 2005.

17 W. D. Pan, C. Sung, Y. M. Zhang, G. Y. Liang, P. Sinaÿ and S. P. Vincent, Chem. - Eur. J., 2007, 13, 1471.

18 S. F. Wnuk and M. J. Robins, Can. J. Chem., 1991, 69, 334.

19 R. H. Grubbs, in Handbook of metathesis, Wiley-VCH, Weinheim, Germany, 2003.

20 (a) T. M. Trnka and R. H. Grubbs, Acc. Chem. Res., 2001, 34, 18; (b) A. B. Flynn and W. W. Ogilvie, Chem. Rev., 2007, 107, 4698.

21 (a) A. K. Chatterjee, T. L. Choi, D. P. Sanders and R. H. Grubbs, J. Am. Chem. Soc., 2003, 125, 11360; (b) S. J. Connon and S. Blechert, Angew. Chem., Int. Ed., 2003, 42, 1900.

22 D. Andrei and S. F. Wnuk, Org. Lett., 2006, 8, 5093.

23 (a) R. S. Ranganathan, G. H. Jones and J. G. Moffatt, J. Org. Chem., 1974, 39, 290; (b) S. Eppacher, P. K. Bhardwaj, B. Bernet, J. L. B. Gala, T. Knopfel and A. Vasella, Helv. Chim. Acta, 2004, 87, 2969.

24 W. J. Dunstan, H. Fazakerley, T. G. Halsall and E. R. H. Jones, Croat. Chem. Acta, 1957, 29, 173.

25 A. Ensminger, PhD Thesis, Université Louis Pasteur, Strasbourg, France, 1974.

26 C. Samoljowicz, M. Bienek, A. Zarecki, R. Kadyrov and K. Grela,J. Chem. Soc., Chem. Commun., 2008, 6282.

27 V. Voorhees and R. Adams, J. Am. Chem. Soc., 1922, 44, 1397.

28 J. A. Osborn, F. H. Jardine, J. F. Young and G. Wilkinson, J. Chem. Soc. A, 1966, 1711.

29 R. Crabtree, Acc. Chem. Res., 1979, 12, 331.

30 (a) C. E. Miller, J. Chem. Educ., 1965, 42, 254; (b) J. L. G. Spears and J. S. Hutchinson, J. Chem. Phys., 1988, 88, 240.

31 J. W. Hamersma and E. I. Snyder, J. Org. Chem., 1965, 30, 3985.

32 J. Toulouse, PhD Thesis, Université de Strasbourg, Strasbourg, France, 2011.

33 J. M. Renoux and M. Rohmer, Eur. J. Biochem., 1985, 151, 405.

34 H. Budzikiewicz, J. M. Wilson and C. Djerassi, J. Am. Chem. Soc., 1963, 85, 3688.

35 W. C. Still, M. Kahn and A. Mitra, J. Org. Chem., 1978, 43, 2923.

36 S. Hestrin and M. Schramm, Biochem. J., 1954, 58, 345. 